\title{
Gahnite, chrysoberyl and beryl co-occurrence as accessory minerals in a highly evolved peraluminous pluton: The Belvís de Monroy leucogranite (Cáceres, Spain)
}

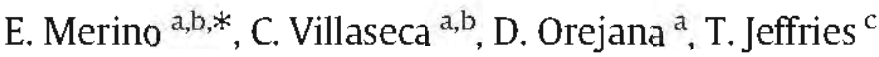 \\ ${ }^{a}$ Dpto de Petrologia y Geoquimica, Faculad de Ciencias Geologicas, Universidad Complutense, 28040 Mad rid, Spain \\ Instituto de Geociencias IGEO (UCM, CSIC), 28040 Madrid Spain \\ c Department of Earth Science, The Natwal History Mnseum, SW7 5BD London, England, United Kingdom
}

A B S T R A C T

\begin{abstract}
Gahnite $\left(\mathrm{ZnAl}_{2} \mathrm{O}_{4}\right)$, chrysoberyl ( $\left.\mathrm{BeAl}_{2} \mathrm{O}_{4}\right)$ a n d b e r y $1\left(\mathrm{~B} \mathrm{e}_{3} \mathrm{Al}_{2} \mathrm{Si}_{6} \mathrm{O}_{18}\right)$ have been found as accessory minerals in the extemal, highly fractionated, leucogranitic unit within the Hercynian reversely zoned Belvis de Monroy pluton (westernmost part of the Montes de Toledo batholith, Cáceres, Spain). The highly felsic ( $\mathrm{SiO}{ }_{2}$ $>72 \mathrm{wt} . \%$ ) and peraluminous ( $A C \mathrm{NK}>1.2$ ) character of this leucogranite, together with the high content of some incompatible elements (F, Li, B, and $P$ ), seems to be a primary consequence of fractional crystallization in a magmatic closed-system. The high Be contents and $\mathrm{Zn} / \mathrm{Fe}_{\text {Total }}$ ratio $(>0.01)$ are relevant factors which have favoured the precipitation of these minerals. Moreover, the $\mathrm{Si}, \mathrm{Al}, \mathrm{P}, \mathrm{B}$, and $\mathrm{F}$ activities might be high, favouring the magmatic crystallization of such exotic mineral phases together with Be-rich cordierite, F-rich micas, sillimanite and Al-rich phosphates. In fact, the interplay between the silica and alumina activities likely controls the stabilization and the preferential crystallization of gahnite + chrysoberyl or beryl + chrysoberyl assemblages in mm-sized microdomains. The $P-T$ crystallization conditions are constrained by the muscovite and sillimanite stability fields and the minimum granite $\mathrm{Al}_{2} \mathrm{O}_{3}$-saturated solidus, and have been estimated at temperatures berween 670 and $700^{\circ} \mathrm{C}$, and pressures between 1 and 2 kbar.
\end{abstract}

\section{Introduction}

The co-occurrence of gahnite (Zn-rich hercynite), chrysoberyl and beryl is uncommon in igneous rocks. This mineral association has only been described in Na-metasomatized pegmatites (Alfonso and Melgarejo, 2008), but chrysoberyl was interpreted as a secondary product of beryl replacement. Beryl is a common accessory mineral in rare-element granitic pegmatites (Alfonso and Melgarejo, 2008; Černý et al., 2003; Charoy, 1999; Rao et al., 2011; Thomas et al., 2009, 2011; Tindle and Breaks, 1998; Uher et al., 2010), or in highly evolved granites (Charoy, 1999; Charoy and Noronha, 1996). Occasionally, it has been found associated with chrysoberyl in Be-rich pegmatites (González del Tánago, 1991; Soman and Nair, 1985). The mineral association gahnite 1 chrysoberyl has been previously found in some Al-rich pegmatites (Jacobson and Webb, 1947), but never associated with beryl. However, gahnite micro-inclusions in large pegmatitic beryl crystals have also been reported (Uher et al., 2010; Zhaolin et al., 1999), although

\footnotetext{
* Corresponding author at: Universidad Complutense de Madrid (UCM), Facultad de Ciencias Geológicas, c/José Antonio Novais 2, 28040 Madrid, Spain. Tel.: +34 913944903; fax: + 34915442535.

E-mail addresses: enriqmer@ucm.es (E. Merino),granito@ucm.es (C. Villaseca), dorejana@ucmes (D. Orejana), t.jeffries@nhm.ac.uk (T. Jeffries).
}

interpreted as crystallized from an immiscible melt included during the beryl crystal growth.

The Belvis de Monroy granite, located in central Spain, is a singular felsic intrusion in part due to the presence of an uncommon group of accessory minerals, among which is the gahnite-chrysoberyl-beryl association. This pluton is a highly evolved leucogranite enriched in incompatible elements, such as P, F, Li, Be, Rb, Nb, Ta, U, Cs and Sn. The Belvis pluton shows a reverse zoning with an enrichment of incompatible elements and a depletion of mafic components towards the border unit of the pluton. The exotic mineral assemblage, composed of Be-rich cordierite, sillimanite, (Al-Li)-rich micas, gahnite, chrysoberyl, beryl and a variety of $\mathrm{Al}-\mathrm{Fe}-(\mathrm{Mn})$-rich phosphates, appears in the most external part of the massif. A similar mineral assemblage has also been found in the associated aplopegmatitic dike swarm surrounding the Belvis pluton. To our knowledge, this is the first report of the assemblage gahnite + beryl + chrysoberyl as magmatic accessory minerals in a felsic igneous pluton. Nonetheless, as described in granulite-facies gneisses (Downes and Bevan, 2002), the three Al-rich minerals have not been observed in mutual contact, suggesting a lack of chemical equilibrium, thus not forming a true magmatic paragenesis.

The present study is focused on the origin and the relationships between the highly fractionated granitic facies that conforms the reversely zoned Belvís pluton, with special emphasis on the origin and 
crystallization conditions of the Al-Be-Zn-rich accessory minerals (chrysoberyl, beryl and gahnite) in its most external granitic unit. We discuss the chemical and thermodynamic factors (mainly silica and alumina activity) that control the crystallization of this rare mineral assemblage confined to specific small-scale (mm-size) chemical microdomains.

\section{Geological setting}

The Belvís de Monroy pluton is located in the westernmost part of the Montes de Toledo batholith (MTB), within the Central Iberian Zone (ClZ, Iberian Massif; Fig. 1A B). This batholith is an $\mathrm{E}$ to $\mathrm{W}$ linear plutonic array composed of almost 20 granitoid bodies which occupies an area of circa $2000 \mathrm{~km}^{2}$ and extends about $200 \mathrm{~km}$ long from Madridejos (Toledo) to Belvís de Monroy (Cáceres). This granitic batholith intrudes into low-grade Neoproterozoic to lower Silunian metasedimentary rocks (Fig. 1B) generating a wide contact metamorphic aureole (IGME, 1985, 1987, 1989). The Neoproterozoic sequences, which belong to the so called Schist-Greywacke Complex, consist of an alternation of shales and sandstones with occasional conglomerates, calcareous mudstones and limestones interbedding (Valladares et al., 2002). Cambrian metasediments are found in the upper part of these sequences (Liñán et al., 2002). A thickness of more than $4000 \mathrm{~m}$ has been estimated for both sequences. The Ordovician and Silurian metasediments are represented by alternating conglomerates, shales, sandstones and quartzites, occasionally found as roof-pendants on top of the granitic cupolas. All these metasedimentary sequences were folded during the Hercynian $\mathrm{D}_{1}$ compressional event (Ábalos et al., 2002) and developed strike-slip dextral shear zones during the $\mathrm{D}_{2}$ and $\mathrm{D}_{3}$ events. Migmatization and partial melting events in the northern part of Central Spain (Spanish Central System) have been assigned to the metamorphic peak related to the Hercynian $\mathrm{D}_{2}$ ductile deformation phase $(\sim 330 \mathrm{Ma}$; Castiñeiras et al., 2008).

Although the batholith defines a continuous plutonic array, the westem and eastern sectors display contrasted geochemical and isotopic features (Villaseca et al., 2008). The eastern segment of this batholith (E-MTB) has been interpreted as derived from partial melting of meta-igneous sources (mainly from lower crustal levels). This metaigneous derivation is based on the higher $\mathrm{CaO}, \mathrm{Na}_{2} \mathrm{O}$ and lower $\mathrm{Al}_{2} \mathrm{O}_{3}$, $\mathrm{P}_{2} \mathrm{O}_{5}$ and $\mathrm{Rb}$ contents when compared to the western part of the batholith (W-MTB), and on their contrasted isotopic ( $\mathrm{Sr}, \mathrm{Nd}$, and $\mathrm{Pb}$ ) signatures (Villaseca et aL, 2008). More detailed information of the eastern part of the batholith can be found in Andonaegui (1990) and Andonaegui and Villaseca (1998). A whole-rock Rb-Sr isochron in a pluton of this segment yields an emplacement age of $320 \pm 8 \mathrm{Ma}$ (Mora-las Ventas intrusion; Andonaegui, 1990). On the contrary, the

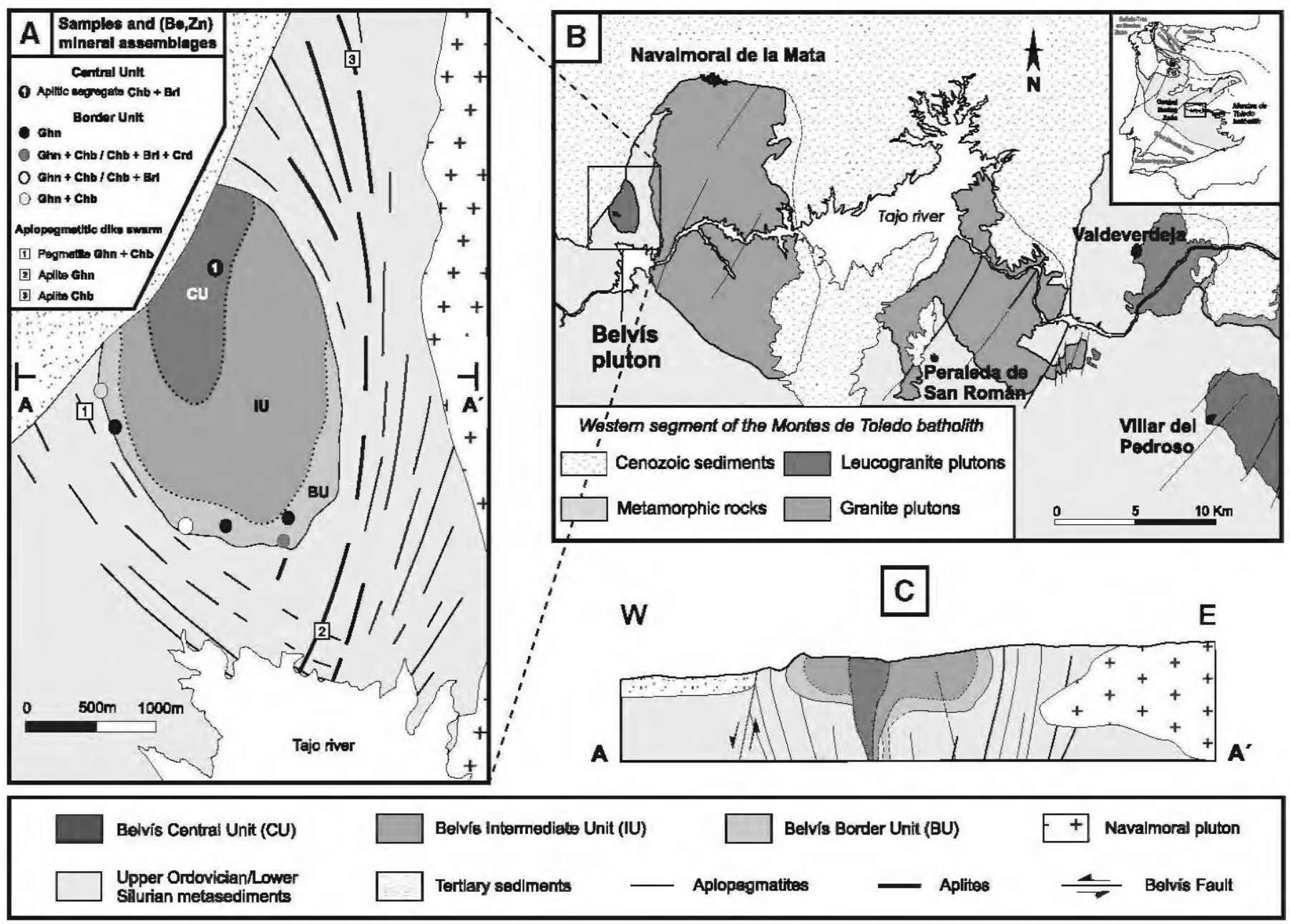

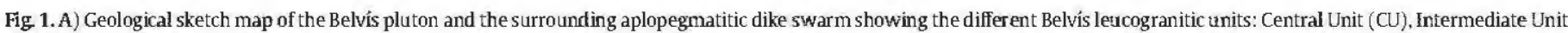

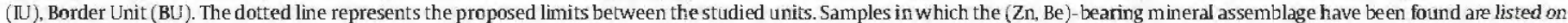

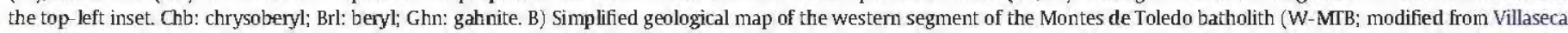

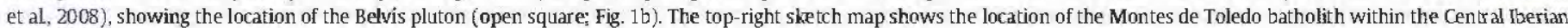
Zone. C) Schematic W-E geological cross-section of the Belvis pluton. 
geochemistry and the isotope signatures of the W-MTB suggest that this granitic segment is mostly derived from metasedimentary Neoproterozoic sequences, and particularly from the Schist-Greywacke Complex, which is characterized by high phosphorus concentrations and a range of initial isotopic ( $\mathrm{Sr}, \mathrm{Nd}$ ) ratios similar to that measured in the granitoids (Villaseca et al, 2008). A recent study has provided an average $\mathrm{U}-\mathrm{Th}-\mathrm{Pb}$ monazite age of $314 \pm 3 \mathrm{Ma}$ for the Belvís intrusion (Orejana et al., 2012).

The Belvis leucogranitic pluton is the most highly fractionated body of the MTB (Villaseca et al., 2008). It intrudes into low-grade Lower Palaeozoic (Upper Ordovician to Lower Silurian) metasediments, consisting of alternating sandstone and shale (Fig. 1A). The intrusion induces a zoned contact metamorphic aureole, showing low-pressure ( $<2 \mathrm{kbar}$ ) mineral associations: i) K-feldspar + sillimanite + biotite \pm cordierite, in the nearest contact, and ii) andalusite + biotite + muscovite \pm cordierite \pm sillimanite in the outer zone (IGME, 1987; E. Merino, personal communication). Local tourmalinization and generation of F-rich phosphates occur within the closest contact with the leucogranite. This pluton crops-out over an area of about $5 \mathrm{~km}^{2}$. The NW part of the Belvís pluton is cross-cut by a NE to SW late-Hercynian inverse fault (Belvís Fault), reactivated during the Alpine orogeny, and covered by Palaeogene and Neogene sediments of the Tajo basin (IGME, 1987; Fig. 1A).

The Ordovician to Silurian metasedimentary sequences are also intruded by a heterogeneous aplopegmatitic dike-system, which surrounds the Belvis pluton (Fig. 1A). The thickness of these dikes varies from centimetres to less than $5 \mathrm{~m}$. Aplopegmatitic dikes with $\mathrm{N}-\mathrm{S}$ to $\mathrm{NE}-\mathrm{SW}$ direction $\left(\mathrm{N} 0^{\circ}-\mathrm{N} 20^{\circ}\right)$, located to the east of the pluton, crosscut another previous aplopegmatitic system (NW-SE, from $\mathrm{N} 110^{\circ}$ to $\mathrm{N} 160^{\circ}$ ), emplaced to the westem part of the Belvis pluton (Fig. 1A). Both dike complexes seem to be sligh tly younger, or almost coetaneous, with the emplacement of the Belvis pluton, as they are occasionally crosscut and partially bulged by the granitic intrusion. A schematic cross-section is given to illustrate the suggested geometry of the pluton at depth (Fig. 1C).

\section{Analytical methods}

Around 55 fresh samples from 40 field stations from the Belvis pluton and the surrounding aplopegmatitic dike complex were collected for petrographic characterization Five representative samples from the different Belvis units were selected for whole-rock analyses. The material processed and crushed was about $8 \mathrm{~kg}$ per sample, separating a fragment of each sample for thin and thick section analyses (petrography under transmitted light microscope, EPMA and LA-ICP-MS mineral analyses). Crushing was performed using a steel jaw crusher, followed by milling with a disc mill and an agate mortar, respectively. A last sieving process was carried out in order to avoid possible grain sizes higher than $0.3 \mathrm{~mm}$.

Whole-rock analyses (major and trace elements) of the different Belvis units were carried out at ACTLABS (Ancaster, Ontario, Canada). Whole-rock major and trace-element compositions are presented in Table 1 . The samples were fused using a $\mathrm{LBOO}_{2}$ flux and dissolved with $\mathrm{HNO}_{3}$. The solutions were analyzed by inductively coupled plasma atomic emission spectrometry (ICP-AES) for major elements, whereas trace elements were determined by inductively coupled plasma mass spectrometry (ICP-MS). Uncertainties in major elements are bracketed between 1 and $3 \%$ relative, except for MnO (5-10\%). The precision of ICP-MS analyses at low concentration levels has been evaluated from repeated analyses of the intemational standards BR, DR-N, UB-N, AN-G and $\mathrm{GH}$. The precision for Rb, Sr, Zr, Y, V, and $\mathrm{Hf}$ and most of the REE ranges from 1 to $5 \%$ and between 5 and $10 \%$ for the rest of trace elements. Some granite samples have concentrations of certain elements below detection limits (V: 5 ppm, Cr: 20 ppm, Sc: 1 ppm, Co: 10 ppm, Cu: $10 \mathrm{ppm}$, As: $5 \mathrm{ppm}$, Sb: $0.2 \mathrm{ppm}$, and Bi: $0.1 \mathrm{ppm}$ ) and almost all the granites have $\mathrm{Ni}<20 \mathrm{ppm}, \mathrm{Mo}<2 \mathrm{ppm}, \mathrm{Ag}<0.5 \mathrm{ppm}$, and In $<0.1 \mathrm{ppm}$. More information on the procedure, precision and accuracy of ACTLABS ICP-MS analyses can be found at www.actlabs.com. F and Li contents have been detemined at the Instituto Geologico y Minero de España (IGME) laboratories. F was extracted by pyrohydrolysis and the element abundance was determined by spectrophotometric methods. After sample digestion with $\mathrm{HF}-\mathrm{HNO}_{3}-\mathrm{HClO}_{4}$, Li was determined by atomic absorption spectrophotometry. An analytical error of $\pm 10 \%$ has been estimated.

Table 1

Whole-rock major (wtg) and trace-element (ppm) composition and isotopic (Sr, Nd) signature of the Belvis granites.

\begin{tabular}{|c|c|c|c|c|c|c|}
\hline \multirow[b]{2}{*}{ Sample } & \multicolumn{2}{|l|}{ Belvis CU } & \multirow{2}{*}{$\frac{\text { Belvis IU }}{106796}$} & \multicolumn{3}{|c|}{ Belvis BU } \\
\hline & 111401 & 112106 & & 106792 & 106793 & 111329 \\
\hline $\mathrm{SiO}_{2}$ & 73.46 & 72.02 & 74.08 & 73.34 & 74.51 & 72.71 \\
\hline $\mathrm{TiO}_{2}$ & 0.18 & 0.114 & 0.1 & 0.04 & 0.03 & 0.044 \\
\hline $\mathrm{Al}_{2} \mathrm{O}_{3}$ & 15.19 & 14.75 & 14.87 & 15.17 & 14.85 & 14.44 \\
\hline $\mathrm{Fe}_{2} \mathrm{O}_{3}$ & 1.31 & 1.07 & 0.9 & 0.5 & 0.37 & 0.52 \\
\hline $\mathrm{MnO}$ & 0.021 & 0.022 & 0.02 & 0.05 & 0.02 & 0.013 \\
\hline $\mathrm{MgO}$ & 0.32 & 0.24 & 0.19 & 0.09 & 0.06 & 0.3 \\
\hline $\mathrm{CaO}$ & 0.45 & 0.51 & 0.46 & 0.39 & 0.41 & 0.56 \\
\hline $\mathrm{Na}_{2} \mathrm{O}$ & 3.41 & 3.57 & 3.77 & 4.11 & 4.3 & 4.21 \\
\hline $\mathrm{K}_{2} \mathrm{O}$ & 4.76 & 4.6 & 3.96 & 3.84 & 3.68 & 3.8 \\
\hline $\mathrm{P}_{2} \mathrm{O}_{5}$ & 0.47 & 0.53 & 0.63 & 0.85 & 0.76 & 0.66 \\
\hline LOI & 1.33 & 1.1 & 1.19 & 0.99 & 0.94 & 1.64 \\
\hline Total & 100.9 & 98.53 & 100.2 & 99.37 & 99.92 & 98.9 \\
\hline $\mathrm{F}$ & 410 & 560 & 2087 & 1173 & 826 & 1279 \\
\hline $\mathrm{Li}$ & 150 & 132 & 289 & 219 & 85.8 & 212 \\
\hline $\mathrm{Ba}$ & 167 & 73 & 63 & 16 & 16 & 47 \\
\hline $\mathrm{Rt}$ & 355 & 354 & 459 & 569 & 430 & 428 \\
\hline $\mathrm{Sr}$ & 50 & 29 & 97 & 48 & 123 & 110 \\
\hline $\mathrm{Pb}$ & 31 & 27 & 18 & 10 & 10 & 20 \\
\hline Th & 7.99 & 2.82 & 1.9 & 0.73 & 0.59 & 1.21 \\
\hline $\mathrm{U}$ & 7.68 & 12.4 & 6.82 & 13.5 & 11.5 & 10.5 \\
\hline $\mathrm{Zr}$ & 78 & 46 & 44 & 28 & 20 & 34 \\
\hline $\mathrm{Nb}$ & 10.8 & 13.7 & 13.5 & 14.4 & 11.7 & 13.3 \\
\hline $\mathrm{Y}$ & 7.9 & 8.1 & 7.3 & 2.1 & 2.9 & 4.1 \\
\hline Sc & 3 & 2 & 2 & 1 & $<1$ & 1 \\
\hline $\mathrm{Ga}$ & 24 & 23 & 21 & 21 & 20 & 19 \\
\hline Tà & 1.98 & 2.38 & 5.34 & 4.98 & 5.29 & 3.66 \\
\hline $\mathrm{Hf}$ & 2 & 1.6 & 1.6 & 1.4 & 1.3 & 1.3 \\
\hline $\mathrm{Cs}$ & 26.1 & 17.6 & 70.6 & 13.7 & 16.9 & 31.5 \\
\hline Sn & 24 & 20 & 50 & 34 & 23 & 44 \\
\hline $\mathrm{Be}$ & 5 & 6 & 18 & 54 & 33 & 23 \\
\hline $\mathrm{Zn}$ & 60 & 60 & 50 & 60 & 40 & 40 \\
\hline $\mathrm{Ge}$ & 2.1 & 2.5 & 2.3 & 2.8 & 2.8 & 3.4 \\
\hline $\mathrm{Tl}$ & 1.89 & 2.13 & 2.98 & 3.49 & 2.27 & 2.25 \\
\hline $\mathrm{Bì}$ & 1.9 & 10.8 & 3.3 & 2.1 & 1.1 & 2.2 \\
\hline $\mathrm{La}$ & 12.1 & 6.62 & 5 & 1.73 & 1.46 & 2.65 \\
\hline $\mathrm{Ce}$ & 27.6 & 13.9 & 11.3 & 3.84 & 3.23 & 6.09 \\
\hline $\operatorname{Pr}$ & 3.64 & 1.77 & 1.3 & 0.42 & 0.35 & 0.75 \\
\hline Nd & 14.6 & 6.57 & 5.38 & 1.62 & 1.47 & 2.85 \\
\hline $\mathrm{sm}$ & 3.52 & 1.82 & 1.34 & 0.37 & 0.38 & 0.77 \\
\hline $\mathrm{E} \mathbf{1}$ & 0.352 & 0.179 & 0.153 & 0.034 & 0.03 & 0.074 \\
\hline $\mathrm{Gd}$ & 2.77 & 1.73 & 1.45 & 0.38 & 0.41 & 0.81 \\
\hline Tb & 0.43 & 0.32 & 0.28 & 0.07 & 0.09 & 0.14 \\
\hline Dy & 1.93 & 1.63 & 1.47 & 0.38 & 0.51 & 0.78 \\
\hline $\mathrm{Ho}$ & 0.27 & 0.24 & 0.2 & 0.06 & 0.08 & 0.13 \\
\hline $\mathrm{Er}$ & 0.68 & 0.53 & 0.48 & 0.15 & 0.21 & 0.33 \\
\hline $\mathrm{Tm}$ & 0.096 & 0.076 & 0.065 & 0.021 & 0.031 & 0.044 \\
\hline $\mathrm{Yb}$ & 0.54 & 0.43 & 0.39 & 0.13 & 0.18 & 0.25 \\
\hline $\mathrm{L} \iota$ & 0.068 & 0.06 & 0.053 & 0.02 & 0.024 & 0.034 \\
\hline$\sum \mathrm{REE}$ & 68.6 & 35.88 & 28.86 & 9.23 & 8.46 & 15.7 \\
\hline $\mathrm{Zn} / \mathrm{Fe}$ Toral & 0.007 & 0.008 & 0.008 & 0.018 & 0.016 & 0.011 \\
\hline $\mathrm{T}^{\mathrm{WGH}}$ & 746.32 & 702.19 & 703.17 & 669.98 & 645.64 & 677.71 \\
\hline $\mathrm{T}^{\mathrm{M}}$ & 774.00 & 740.13 & 735.67 & 692.06 & 684.57 & 703.24 \\
\hline$\left({ }^{87} \mathrm{Sr} /{ }^{86} \mathrm{Sr}\right)$ & n.a & 0.8746 & 0.7768 & 0.8560 & 0.7604 & 0.7699 \\
\hline$\left({ }^{87} \mathrm{Sr} /{ }^{86} \mathrm{Sr}\right)_{300}$ & n.a & 0.7213 & 0.7180 & 0.7074 & 0.7170 & 0.7215 \\
\hline$\left({ }^{143} \mathrm{Nd} /{ }^{144} \mathrm{Nd}\right)$ & n.a & 0.5123 & 0.5123 & 0.5122 & 0.5123 & 0.5123 \\
\hline$\varepsilon(\mathrm{Nd})_{3,00}$ & n.a & -6.08 & -5.49 & -5.48 & -5.34 & -6.18 \\
\hline
\end{tabular}

$\mathrm{T}^{\text {WBH: }}$ Zircon saturation temperatures $\left(\right.$ in $\left.{ }^{\circ} \mathrm{C}\right)$ calculated according to Watson and Harrison (1983) geothermometer.

$\mathrm{T}^{\mathrm{M}}$ : Monazite saturation temperatures (in ${ }^{\circ} \mathrm{C}$ ), according to Montel (1993) geothermometer, calculated at $1 \mathrm{~g}^{\circ} \mathrm{H}_{2} \mathrm{O}$.

$\left({ }^{87} \mathrm{Sr} /{ }^{86} \mathrm{Sr}\right)_{300}$ and $\varepsilon(\mathrm{Nd})_{300}$ isotopic ratios calculated at $300 \mathrm{Ma}$. n.a.: not analyzed. 
Table 2

Mean major (wt.\%) and trace-element composition (ppm) of K-feld spar and plagioclase from the Belvis granites.

\begin{tabular}{|c|c|c|c|c|c|c|c|c|c|c|c|c|c|c|c|c|c|c|c|c|}
\hline \multirow{2}{*}{$\begin{array}{l}\text { Sample } \\
\text { Mineral }\end{array}$} & \multicolumn{4}{|c|}{ Belvís CU } & \multicolumn{4}{|c|}{ Belvis IU } & \multicolumn{4}{|c|}{ Belvís BU } & \multicolumn{4}{|c|}{ Aplopegmatites } & \multicolumn{4}{|c|}{ Aplitic segregate in $\mathrm{CU}$} \\
\hline & \multicolumn{2}{|l|}{$\mathrm{Kfs}$} & \multicolumn{2}{|l|}{$\mathrm{Pl}$} & \multicolumn{2}{|l|}{$\overline{\mathrm{Kfs}}$} & \multicolumn{2}{|l|}{$\mathrm{Pl}$} & \multicolumn{2}{|l|}{$\overline{\mathrm{Kfs}}$} & \multicolumn{2}{|l|}{$\mathrm{Pl}$} & \multicolumn{2}{|l|}{$\overline{\mathrm{Kfs}}$} & \multicolumn{2}{|l|}{$\mathrm{Pl}$} & \multicolumn{2}{|l|}{$\overline{\mathrm{Kfs}}$} & \multicolumn{2}{|l|}{$\mathrm{Pl}$} \\
\hline$\overline{\text { No. of analyses }}$ & $\overline{4,3}$ & & 5,3 & & 6.2 & & 5,2 & & 17,14 & & 40,19 & & 22,7 & & $\overline{31,8}$ & & 9,5 & & $\overline{7,4}$ & \\
\hline $\mathrm{SiO}_{2}$ & 63.11 & $(1.21)$ & 65.37 & $(0.32)$ & 62.71 & $(0.36)$ & 65.86 & $(0.47)$ & 63.10 & $(0.47)$ & 65.98 & $(0.62)$ & 63.01 & $(0.63)$ & 66.09 & $(0.84)$ & 63.04 & $(0.33)$ & 65.62 & $(0.48)$ \\
\hline $\mathrm{Al}_{2} \mathrm{O}_{3}$ & 18.99 & $(0.24)$ & 20.89 & (0.49) & 19.24 & $(0.32)$ & 20.60 & $(0.42)$ & 18.92 & $(0.32)$ & 20.35 & $(0.41)$ & 18.79 & $(0.24)$ & 20.48 & $(0.41)$ & 18.71 & $(0.14)$ & 20.35 & $(0.22)$ \\
\hline $\mathrm{CaO}$ & 0.01 & $(0.01)$ & 0.76 & $(0.28)$ & 0.01 & $(0.01)$ & 0.59 & $(0.15)$ & 0.01 & $(0.01)$ & 0.44 & $(0.18)$ & 0.01 & $(0.01)$ & 0.50 & $(0.22)$ & 0.01 & $(0.01)$ & 0.61 & $(0.20)$ \\
\hline $\mathrm{Na}_{2} \mathrm{O}$ & 2.30 & $(0.78)$ & 11.53 & $(0.29)$ & 0.54 & $(0.12)$ & 11.05 & $(0.42)$ & 0.79 & $(0.26)$ & 11.59 & $(0.37)$ & 0.52 & $(0.25)$ & 11.56 & $(0.23)$ & 1.14 & $(0.22)$ & 11.78 & $(0.18)$ \\
\hline $\mathrm{K}_{2} \mathrm{O}$ & 12.70 & (1.59) & 0.22 & $(0.06)$ & 16.12 & $(0.17)$ & 0.21 & $(0.06)$ & 15.52 & $(0.58)$ & 0.22 & $(0.09)$ & 15.79 & $(0.40)$ & 0.21 & $(0.07)$ & 15.42 & $(0.43)$ & 0.20 & $(0.07)$ \\
\hline $\mathrm{P}_{2} \mathrm{O}_{5}$ & 0.51 & $(0.22)$ & 0.52 & $(0.05)$ & 0.78 & $(0.08)$ & 0.59 & $(0.17)$ & 0.81 & $(0.18)$ & 0.71 & $(0.18)$ & 0.77 & $(0.23)$ & 0.68 & $(0.14)$ & 0.79 & $(0.09)$ & 0.81 & $(0.16)$ \\
\hline $\mathrm{F}$ & 0.01 & $(0.01)$ & 0.01 & $(0.00)$ & 0.01 & $(0.02)$ & 0.02 & $(0.02)$ & 0.02 & $(0.02)$ & 0.02 & $(0.02)$ & 0.02 & $(0.02)$ & 0.02 & $(0.02)$ & 0.01 & $(0.01)$ & 0.02 & $(0.02)$ \\
\hline 初 & 0.03 & $(0.03)$ & 3.48 & (1.27) & 0.03 & $(0.03)$ & 2.86 & $(0.76)$ & 0.04 & $(0.04)$ & 2.03 & $(0.87)$ & 0.06 & $(0.05)$ & 2.32 & $(1.00)$ & 0.06 & $(0.07)$ & 2.75 & $(0.90)$ \\
\hline$\% \mathrm{Ab}$ & 21.77 & (8.14) & 95.34 & (1.14) & 4.86 & $(1.04)$ & 95.93 & $(0.94)$ & 7.15 & (2.37) & 96.77 & $(1.17)$ & 6.55 & (2.18) & 96.53 & (1.14) & 10.09 & $(1.96)$ & 96.20 & (1.25) \\
\hline$\% 0 \mathrm{r}$ & 78.20 & $(8.13)$ & 1.18 & $(0.33)$ & 95.10 & $(1.05)$ & 1.21 & $(0.41)$ & 92.81 & (2.36) & 1.20 & $(0.51)$ & 93.39 & (2.19) & 1.14 & $(0.36)$ & 89.85 & $(2.00)$ & 1.05 & (0.36) \\
\hline Li & 15.75 & $(9.90)$ & 0.64 & $(0.00)$ & 18.80 & $(9.00)$ & 15.82 & & 113 & $(72.97)$ & 60.64 & $(84.38)$ & 95.71 & $(97.02)$ & 25.78 & $(8.68)$ & 7.96 & $(2.27)$ & 32.30 & $(0.00)$ \\
\hline $\mathrm{Be}$ & 2.88 & $(0.17)$ & 10.05 & $(0.10)$ & 10.31 & $(2.50)$ & 10.68 & (1.82) & 8.52 & $(3.22)$ & 13.92 & $(3.43)$ & 3.77 & $(1.83)$ & 9.86 & (2.4) & 3.96 & $(0.94)$ & 12.06 & (3.64) \\
\hline B & b.d.l. & & 5.04 & $(0.00)$ & b.d.l. & & b.d.l. & & 10.19 & (1.94) & 8.84 & $(3.18)$ & 17.51 & $(13.29)$ & 8.95 & $(2.65)$ & b.d.l. & & 7.99 & $(2.24)$ \\
\hline Sc & 2.25 & $(0.15)$ & 2.46 & $(0.17)$ & 4.04 & $(0.10)$ & 4.42 & $(0.00)$ & 4.56 & (1.16) & 4.48 & $(0.89)$ & 3.40 & $(0.16)$ & 3.48 & $(0.23)$ & 2.61 & $(0.15)$ & 2.66 & $(0.19)$ \\
\hline $\mathrm{Zn}$ & 2.73 & $(0.00)$ & 2.50 & $(0.00)$ & 2.59 & $(1.42)$ & b.d.l. & & 4.65 & $(2.12)$ & 4.31 & $(2.89)$ & 3.37 & $(2.07)$ & 2.94 & (2.14) & 2.62 & $(0.68)$ & 8.79 & $(6.52)$ \\
\hline $\mathrm{Rb}$ & 745 & (41) & 0.41 & $(0.04)$ & 1495 & (115) & 1.48 & $(1.22)$ & 1358 & (153) & 3.36 & $(1.89)$ & 896 & (87) & 1.89 & (1.11) & 773 & (67) & 4.88 & $(5.46)$ \\
\hline Cs & 20.97 & (0.89) & b.d.l. & & 23.50 & (14.50) & 0.17 & $(0.00)$ & 22.22 & $(8.17)$ & 0.73 & $(0.50)$ & 23.71 & $(4.96)$ & 0.17 & $(0.00)$ & 17.46 & $(2.38)$ & 0.55 & $(0.46)$ \\
\hline $\mathrm{Sr}$ & 27.33 & $(4.64)$ & 31.40 & $(1.70)$ & 27.40 & $(2.00)$ & 25.95 & (1.35) & 11.50 & $(7.37)$ & 14.20 & $(7.91)$ & 12.56 & $(6.26)$ & 23.48 & $(10.80)$ & 23.34 & $(1.03)$ & 27.73 & (4.43) \\
\hline $\mathrm{Ba}$ & 206 & (37.33) & 5.14 & $(0.40)$ & 44.30 & $(1.40)$ & 4.83 & $(0.58)$ & 78.18 & $(46.06)$ & 230 & $(1.34)$ & 87.94 & $(52.62)$ & 3.66 & $(1.64)$ & 124 & (13.44) & 3.77 & $(0.71)$ \\
\hline Eu & 0.19 & $(0.05)$ & 0.22 & $(0.06)$ & 0.15 & $(0.01)$ & 0.15 & $(0.04)$ & 0.05 & $(0.09)$ & 0.08 & $(0.02)$ & 0.10 & $(0.02)$ & 0.14 & $(0.05)$ & 0.13 & $(0.01)$ & 0.12 & $(0.03)$ \\
\hline $\mathrm{Hf}$ & b.d.l. & & b.d.l. & & b.d.l. & & b.d.l. & & 0.57 & $(0.00)$ & 0.33 & $(0.00)$ & 0.11 & $(0.01)$ & 0.18 & $(0.00)$ & b.d.l & & b.d.l. & \\
\hline $\mathrm{Nb}$ & b.d.l. & & b.d.l. & & b.d.l. & & b.d.l. & & 0.08 & $(0.01)$ & 0.44 & $(0.16)$ & 0.04 & $(0.00)$ & 0.48 & $(0.00)$ & b.d.l. & & 0.17 & $(0.00)$ \\
\hline $\mathrm{Pb}$ & 48.33 & $(2.98)$ & 17.67 & $(1.50)$ & 21.55 & $(0.85)$ & 16.95 & $(0.25)$ & 27.43 & $(8.28)$ & 13.86 & $(2.70)$ & 44.96 & $(4.67)$ & 18.79 & (1.44) & 42.18 & $(2.42)$ & 15.65 & (1.85) \\
\hline
\end{tabular}

Number of analyses refers to EPMA and LA-ICP-MS analyses, respectively.

b.d.li: below detection limit. Numbers in parenthesis refer to 10 mean standard deviations.

Mineral abbreviations are after Kretz (1983). 
Táble 3

Mean major ( wt.\%) and trace-element composition (ppm) of micas from the Belvis granites and cordierite from the BU.

\begin{tabular}{|c|c|c|c|c|c|c|c|c|c|c|c|c|c|c|c|c|c|c|c|c|c|c|}
\hline \multirow{2}{*}{$\begin{array}{l}\text { Sample } \\
\text { Mineral }\end{array}$} & \multicolumn{4}{|c|}{ Belvís CU } & \multicolumn{4}{|c|}{ Belvís IU } & \multicolumn{6}{|c|}{ Belvís BU } & \multicolumn{4}{|c|}{ Aplopegnatites } & \multicolumn{4}{|c|}{ Aplitic segregate in CU } \\
\hline & \multicolumn{2}{|l|}{ Ms } & \multicolumn{2}{|l|}{ Bt } & \multicolumn{2}{|l|}{$\overline{M s}$} & \multicolumn{2}{|l|}{ Bit } & \multicolumn{2}{|l|}{ Ms } & \multicolumn{2}{|l|}{ Bt } & \multicolumn{2}{|l|}{$\mathrm{Crd}$} & \multicolumn{2}{|l|}{$\mathrm{Ms}$} & \multicolumn{2}{|l|}{ Bt } & \multicolumn{2}{|l|}{ Ms } & \multicolumn{2}{|l|}{ Bt } \\
\hline No. of analyses & 4,4 & & 6,3 & & 11,3 & & 6,2 & & 46,21 & & 21,11 & & 9,9 & & 22,9 & & 7,5 & & 3,2 & & 3,2 & \\
\hline $\mathrm{SiO}_{2}$ & 45.36 & $\{0.31\}$ & 34.68 & $(0.46)$ & 45.73 & $(0.34)$ & 35.08 & $(0.53)$ & 45.13 & $\{0.45\rangle$ & 34.82 & $(0.27)$ & 45.07 & $(0.51)$ & 45.52 & $(0.43)$ & 34.65 & $(0.33)$ & 45.69 & $(0.44)$ & 34.59 & $(0.38)$ \\
\hline $\mathrm{TiO}_{2}$ & 0.54 & $\{0.16\}$ & 2.38 & $(0.17)$ & 0.39 & $(0.06)$ & 2.03 & $\{0.11\}$ & 0.30 & $0.10\}$ & 1.52 & $0.39)$ & 0.01 & $(0.01)$ & 0.19 & $(0.16)$ & 1.77 & $0.55\rangle$ & 0.32 & $(0.19\rangle$ & 2.87 & $\langle 0.37\rangle$ \\
\hline $\mathrm{Al}_{2} \mathrm{O}_{3}$ & 35.63 & $(0.17)$ & 21.00 & $(0.26)$ & 35.49 & $(0.61)$ & 21.88 & $(0.46)$ & 34.82 & $(0.59)$ & 21.48 & $(0.37)$ & 29.30 & $(0.46)$ & 35.94 & $(0.74)$ & 21.46 & $(0.56)$ & 34.60 & $(0.36)$ & 20.48 & $(0.30)$ \\
\hline FeO & 1.09 & $(0.16)$ & 19.70 & $(0.51)$ & 1.48 & $(0.14)$ & 20.52 & $(0.59)$ & 1.70 & $(0.20)$ & 21.70 & $(0.99)$ & 14.19 & $(0.28)$ & 1.09 & $(0.36)$ & 21.66 & $(0.63)$ & 1.38 & $(0.13)$ & 21.16 & $(0.08)$ \\
\hline Mno & 0.01 & $\{0.01\}$ & 0.07 & $(0.02)$ & 0.01 & $0.01\}$ & 0.21 & $(0.05)$ & 0.02 & $\{0.02\}$ & 0.19 & $(0.04)$ & 1.05 & $(0.16)$ & 0.02 & $(0.02)$ & 0.06 & $(0.06)$ & 0.01 & $(0.02)$ & 0.02 & $(0.01)$ \\
\hline MgO & 0.68 & $(0.04)$ & 5.26 & $(0.09)$ & 0.69 & $(0.05)$ & 3.25 & $(0.28)$ & 0.59 & $(0.10)$ & 3.32 & $(0.70)$ & 2.07 & $(0.19)$ & 0.35 & $(0.15)$ & 3.47 & $(0.57)$ & 0.59 & $(0.08)$ & $4.6 \overline{6}$ & $(0.21)$ \\
\hline Go & 0.01 & $(0.01)$ & 0.02 & $(0.01)$ & 0.01 & $(0.01)$ & 0.01 & (0.01) & 0.01 & $(0.01)$ & 0.01 & $(0.01)$ & 0.03 & $(0.02)$ & 0.01 & $(0.02)$ & 0.03 & $(0.03)$ & 0.04 & $(0.03)$ & 0.01 & $(0.01)$ \\
\hline $\mathrm{Na}_{2} \mathrm{O}$ & 0.71 & $\{0.05\}$ & 0.48 & $(0.27)$ & 0.69 & $(0.06)$ & 0.09 & $\{0.03\}$ & 0.49 & 0.23 & 0.08 & $(0.03)$ & 2.08 & $(0.12\rangle$ & 0.63 & $(0.11)$ & 0.08 & $\{0.01\rangle$ & 0.68 & $\langle 0.40\rangle$ & 0.13 & $\langle 0.05\rangle$ \\
\hline $\mathrm{K}_{2} \mathrm{O}$ & 9.56 & $(0.15)$ & 8.53 & $(0.14)$ & 9.78 & 0.59 & 9.41 & $(0.09)$ & 10.23 & $\{0 . A 2\}$ & 9.00 & $(0.32)$ & 0.02 & $(0.01\rangle$ & 10.12 & $(0.48)$ & 9.11 & $(0.15\rangle$ & 10.09 & $(0.37)$ & 9.24 & $\langle 0.18\rangle$ \\
\hline NiO & 0.00 & $(0.00)$ & 0.02 & $(0.02)$ & 0.03 & $(0.03)$ & 0.02 & $(0.02)$ & 0.02 & $(0.02)$ & 0.02 & $(0.01)$ & 0.00 & $(0.00)$ & 0.02 & $(0.02)$ & 0.02 & $(0.02)$ & 0.02 & $(0.01)$ & 0.01 & $(0.01)$ \\
\hline $\mathrm{Gr}_{2} \mathrm{O}_{3}$ & 0.04 & $\{0.01\}$ & 0.03 & $(0.01)$ & 0.01 & $\{0.02\}$ & 0.01 & $\{0.02\}$ & 0.03 & $\{0.02\}$ & 0.03 & $(0.02)$ & 0.01 & $(0.01)$ & 0.02 & $(0.02)$ & 0.03 & $(0.02)$ & 0.01 & $\{0.01\}$ & 0.00 & $(0.00)$ \\
\hline $\mathrm{P}_{2} \mathrm{O}_{5}$ & 0.03 & $(0.02)$ & 0.06 & $(0.02)$ & 0.06 & $(0.02)$ & 0.05 & $(0.01)$ & 0.05 & $(0.03)$ & 0.06 & $(0.02)$ & 0.08 & $(0.03)$ & 0.08 & $(0.04)$ & 0.03 & $(0.02)$ & 0.07 & $(0.05)$ & 0.07 & $(0.00)$ \\
\hline $\mathrm{F}$ & 0.30 & $(0.06)$ & 0.71 & $(0.03)$ & 0.61 & $(0.13)$ & 0.90 & $(0.18)$ & 0.50 & $(0.08)$ & 1.18 & (0.11) & 0.01 & $(0.01)$ & 0.24 & (0.12) & 0.92 & $(0.11)$ & 0.23 & $(0.08)$ & 0.57 & $(0.01)$ \\
\hline a & 0.05 & $\{0.05\}$ & 0.16 & $(0.14)$ & 0.00 & $\{0.00\rangle$ & 0.01 & $\{0.00\}$ & 0.01 & $\{0.01\}$ & 0.03 & $(0.02)$ & 0.01 & $\{0.01\rangle$ & 0.01 & $(0.01)$ & 0.01 & $(0.01)$ & 0.15 & $\langle 0.16\rangle$ & 0.04 & $\langle 0.03\rangle$ \\
\hline Mg\# & 0.53 & $\{0.02\}$ & 0.32 & $(0.00\rangle)$ & 0.46 & $\{0.02\}$ & 0.22 & $\{0.02\}$ & 0.38 & 0.03 & 0.21 & $(0.04)$ & 0.21 & $\{0.01\rangle$ & 0.36 & $(0.08)$ & 0.22 & $(0.03)$ & 0.43 & $\{0.05\rangle$ & 0.28 & $\langle 0.01\rangle$ \\
\hline XMs & 0.79 & $(0.01)$ & & & 0.79 & $(0.01)$ & & & 0.82 & $(0.04)$ & & & & & 0.83 & $(0.02)$ & & & 0.80 & $(0.07)$ & & \\
\hline $\mathrm{XPa}$ & 0.10 & $(0.01)$ & & 0.10 & $(0.01)$ & & 0.07 & $(0.03)$ & & & & 0.09 & $(0.02)$ & & & & & & 0.09 & $(0.05)$ & & \\
\hline Li & 481 & (20) & 2217 & $(189)$ & 935 & (28) & 5150 & $(140)$ & 967 & $\{184\}$ & 5225 & $(500)$ & 1906 & (94) & 335 & $(232)$ & 3190 & (208) & 443 & (4) & 1510 & $(100)$ \\
\hline $\mathrm{Be}$ & 11.33 & $(1.29)$ & 4.95 & $(1.55)$ & 11.80 & $(0.73)$ & 9.75 & $(1.25)$ & 18.87 & $(5.00)$ & 8.13 & $(1.25)$ & 3920 & (262) & 12.53 & $(2.56)$ & 8.46 & $(1.00)$ & 11.20 & $(0.20)$ & 4.34 & $(0.91)$ \\
\hline $\mathrm{B}$ & 59.88 & $(5.58\}$ & 10.47 & $(8.28)$ & 41.90 & $(8.73)$ & 4.94 & $(0.00)$ & 66.70 & $(27.01)$ & 5.21 & $(0.94)$ & 4.38 & $(0.63)$ & 87.93 & $(34.70)$ & 4.97 & $(0.89)$ & 41.10 & $(0.60)$ & 8.54 & (1.16) \\
\hline se & 36.25 & $\{16.75\rangle$ & 12.13 & $(3.11)$ & 33.83 & $\{18.71\rangle$ & 4.84 & $(0.09)$ & 12.85 & $\{3.61\}$ & 7.38 & $(2.42)$ & 3.99 & $\{0.34\rangle$ & 17.26 & $(12.68)$ & 10.66 & $\langle 4.41\rangle$ & 61.65 & $\{5.75\rangle$ & 22.65 & $\langle 0.75\rangle$ \\
\hline $\mathrm{Zn}$ & 68.30 & $(5.05)$ & 1403 & $(282)$ & 122 & (11) & 1665 & (65) & 132 & (21) & 1635 & (196) & 493 & (26) & 64 & $(20.10)$ & 1530 & $(40)$ & 68.75 & $(0.05)$ & 1245 & (85) \\
\hline Rb & 1046 & (31) & 2247 & (69) & 1150 & (47) & 2330 & (70) & 1711 & (336) & 3745 & (483) & 138 & (19) & 1079 & $(12 A)$ & 2626 & (65) & 1065 & (15) & 1980 & (80) \\
\hline Cs & 44.90 & $\{7.45\}$ & 406 & $(278)$ & 22.23 & $(1.38\}$ & 321 & (48) & 108 & (99) & 290 & (89) & 338 & (18) & 35.41 & $(7.92)$ & 403 & (263) & 24.00 & $(1.00\}$ & 237 & $\{45\}$ \\
\hline Sr & 1.19 & $(0.08)$ & 3.96 & $(4.82)$ & 1.63 & $(0.73)$ & 0.19 & $(0.03)$ & 0.98 & $(0.86)$ & 0.31 & $(0.22)$ & 0.35 & $(0.13)$ & 0.89 & $(0.52)$ & 0.65 & $(0.36)$ & 1.02 & $(0.02)$ & 2.25 & $(0.75)$ \\
\hline $\mathrm{Ba}$ & 51.00 & $(5.10)$ & 33.90 & $(11.40)$ & 53.83 & $(7.49)$ & 31.30 & $(1.80)$ & 45.81 & $(58.59)$ & 9.01 & $(3.48)$ & 0.67 & $(0.08)$ & 24.16 & $(14.04)$ & 40.04 & $(14.97)$ & 35.20 & $(4.90)$ & 19.50 & $(0.40)$ \\
\hline $\mathrm{Zr}$ & 1.45 & $\{0.51\}$ & 0.84 & $(0.28)$ & 2.02 & $(0.87)$ & 0.42 & $\{0.01\}$ & 1.27 & $0.36\rangle$ & 0.85 & $(0.25)$ & 0.09 & $(0.02)$ & 2.57 & $(2.41)$ & 1.56 & $(0.61)$ & 1.75 & $(0.07\rangle$ & 1.19 & $\{0.19\}$ \\
\hline $\mathrm{HF}$ & 0.15 & $(0.01)$ & 0.13 & $(0.00)$ & 0.19 & $(0.02)$ & 0.08 & $(0.01)$ & 0.15 & $(0.04$ & 0.13 & $(0.01)$ & b.d.l. & & 0.21 & $(0.10)$ & 0.09 & $(0.02)$ & 0.16 & $(0.00)$ & 0.16 & $(0.00)$ \\
\hline $\mathrm{Ta}$ & 10.08 & $(2.12)$ & 40.40 & $(5.93)$ & 11.67 & $(1.28)$ & 61.90 & $(3.20)$ & 31.16 & $(17.08)$ & 241 & (81) & 0.02 & $(0.01)$ & 23.46 & $(10.81)$ & 84.68 & (13.14) & 16.40 & $(1.00)$ & 58.35 & $(2.75)$ \\
\hline Nb & 86.95 & $(22.05)$ & 247 & (33) & 95.97 & (14.69) & 321 & (20) & 139 & (44) & 653 & (199) & 0.04 & $(0.01)$ & 78.62 & $(42.26)$ & 320 & (21) & 139 & (3) & 427 & (34) \\
\hline$w$ & 23.64 & $\{13.63\rangle\}$ & 6.73 & $(1.37)$ & 50.37 & $(12.04)$ & 8.76 & $\{0.19\}$ & 29.29 & $(16.68)$ & 9.55 & (2.21) & b.d.l. & & 25.12 & $(14.81)$ & 9.66 & (1.11) & 59.00 & $\{3.50\rangle$ & 8.30 & (1.11) \\
\hline $\mathrm{Pb}$ & 2.09 & $(0.21)$ & 1.88 & $(1.17)$ & 1.78 & $(0.17)$ & 1.73 & $(0.02)$ & 1.33 & $(0.20)^{\circ}$ & 0.96 & $(0.21)$ & 0.14 & $(0.03)$ & 2.38 & $(0.90)$ & 1.83 & $(0.63)$ & 1.61 & $(0.11)$ & 1.48 & $(0.39)$ \\
\hline
\end{tabular}

Number of analyses refers to EPMA and LA-ICP-MS analyses, respectively.

b.d.l.: below detection limit. Numbers in parenthesis refer to 10 mean standard deviations.

Mineral abbreviations are after Kretz (1983). 
The Sr-Nd whole-rock isotopic analyses were carried out at the CAI de Geocronología y Geoquímica Isotôpica of the Complutense University of Madrid (Spain), using an automated VG Sector 54 multicollector thermal ionization mass spectrometer. Analytical data were acquired in multidynamic mode. The analytical procedures used in this laboratory have been described elsewhere (Reyes et al., 1997). Repeated analyses of the NBS 987 standard gave ${ }^{87} \mathrm{Sr} /{ }^{86} \mathrm{Sr}=0.710234 \pm 30(2 \sigma, \mathrm{n}=12)$ and for the JM Nd standard the values of ${ }^{143} \mathrm{Nd} /{ }^{144} \mathrm{Nd}=0.511854 \pm 3$ ( $2 \sigma, \mathrm{n}=63$ ) were obtained. The $2 \sigma$ error on $€ N d$ calculation is \pm 0.3 .

Major-element mineral compositions have been analyzed at the Centro Nacional de Microscopía Electrốnica "Luis Bru" (Universidad Complutense de Madrid) using a Jeol JXA-8900 M electron microprobe with five wavelength dispersive spectrometers. Analytical conditions were an accelerating voltage of $15 \mathrm{kV}$ and an electron beam current of $20 \mathrm{nA}$, with a beam diameter of $5 \mu \mathrm{m}$. Elements were counted for $10 \mathrm{~s}$ on the peak and $5 \mathrm{~s}$ on each background position. Corrections were made using the ZAF method.

Trace-element analyses of major and accessory minerals were cartied out in situ on selected thick sections ( $\sim 100 \mu \mathrm{m}$ thick) by laser ablationICP-MS at The Natural History Museum, London, using an Agilent 7500cs ICP-MS coupled to an ESI New Wave UP193FX laser source (193 nm short pulse width ArF excimer laser). Mean EPMA and LA-ICP-MS analyses and representative compositions of selected major and accessory minerals are presented in Tables 2 to 5 . The trace-element dataset on

Table 4

Representative major ( $w$ t.\%) and trace-element composition (ppm) of gahnite from the Belvis granites

\begin{tabular}{|c|c|c|c|c|c|}
\hline \multirow[b]{2}{*}{ Sample } & \multicolumn{3}{|l|}{ Belvis BU } & \multirow{2}{*}{$\frac{\text { Pegmatite }}{111545}$} & \multirow{2}{*}{$\frac{\text { Aplopegmatite }}{112099}$} \\
\hline & 111533 & 111533 & 112114 & & \\
\hline \multirow[t]{2}{*}{ Analysis } & 24 & 160 & 46 & 36 & 25 \\
\hline & $\begin{array}{l}\text { Included in } \\
\mathrm{Pl}\end{array}$ & $\begin{array}{l}\text { Included in } \\
\text { Ms }\end{array}$ & $\begin{array}{l}\text { Included in } \\
\mathrm{Pl}\end{array}$ & $\begin{array}{l}\text { Included in } \\
\text { Pl }\end{array}$ & $\begin{array}{l}\text { Included in } \\
\mathrm{Pl}\end{array}$ \\
\hline $\mathrm{Al}_{2} \mathrm{O}_{3}$ & 58.63 & 59.10 & 58.86 & 60.50 & 59.02 \\
\hline FeO & 15.43 & 14.91 & 16.00 & 11.71 & 12.25 \\
\hline $\mathrm{MnO}$ & 0.25 & 0.04 & 0.29 & 0.16 & 0.29 \\
\hline $\mathrm{MgO}$ & 0.37 & 0.42 & 0.43 & 1.26 & 0.34 \\
\hline $\mathrm{Cr}_{2} \mathrm{O}_{3}$ & 0.03 & 0.01 & 0.00 & 0.05 & 0.01 \\
\hline $\mathrm{ZnO}$ & 25.02 & 26.6 & 23.86 & 25.60 & 27.36 \\
\hline Total & 99.73 & 101.04 & 99.47 & 99.29 & 99.26 \\
\hline \multicolumn{6}{|c|}{ No. of ions in formula based on 320 atoms } \\
\hline Al & 16.28 & 16.24 & 16.32 & 16.57 & 16.42 \\
\hline $\mathrm{Fe}$ & 3.04 & 2.91 & 3.15 & 2.28 & 2.42 \\
\hline $\mathrm{Mn}$ & 0.05 & 0.01 & 0.06 & 0.03 & 0.06 \\
\hline $\mathrm{Mg}$ & 0.13 & 0.15 & 0.15 & 0.44 & 0.12 \\
\hline $\mathrm{Cr}$ & 0.01 & 0.00 & 0.00 & 0.01 & 0.00 \\
\hline $\mathrm{Zn}$ & 4.35 & 4.57 & 4.15 & 4.39 & 4.77 \\
\hline g Ghn & 57.5 & 59.92 & 55.25 & 61.54 & 64.76 \\
\hline$\% \mathrm{Hc}$ & 40.14 & 38.08 & 41.95 & 31.89 & 32.83 \\
\hline$\% \mathrm{Sp}$ & 1.71 & 1.90 & 2.02 & 6.12 & 1.61 \\
\hline $6 \mathrm{GlX}$ & 0.65 & 0.09 & 0.77 & 0.45 & 0.80 \\
\hline \multicolumn{6}{|c|}{ LA-ICP-MS trace-element analyses } \\
\hline $\mathrm{Li}$ & 104 & 112 & 143 & 63.0 & 97.1 \\
\hline $\mathrm{Be}$ & 32.3 & 30.4 & 26.0 & 33.4 & 9.20 \\
\hline $\mathrm{V}$ & 6.74 & 46.4 & 7.14 & 4.31 & 0.17 \\
\hline Co & 3.62 & 2.67 & 31.3 & 39.2 & b.d.l. \\
\hline $\mathrm{Zn}^{3}$ & 201,010 & 213,420 & 191,684 & 205,645 & 219,774 \\
\hline $\mathrm{Rt}$ & b.d.1. & b.d.l. & 0.14 & b.d.l. & b.d.l. \\
\hline $\mathrm{Sr}$ & 0.05 & b.d.l. & b.d.l. & b.d.l. & t.d.l. \\
\hline $\mathrm{Zr}$ & 0.16 & b.d.l. & b.d.l. & b.d.l. & 0.07 \\
\hline $\mathrm{Ta}$ & b.d.1. & b.d.l. & b.d.l. & 10.0 & b.d.l. \\
\hline $\mathrm{Nb}$ & b.d.1. & b.d.l. & b.d.l. & 1.01 & b.d.l. \\
\hline $\mathrm{Pb}$ & 0.22 & b.d.l. & 0.14 & 0.17 & 0.14 \\
\hline $\mathrm{U}$ & 0.33 & b.d.l. & 0.09 & b.d.l. & b.d.l. \\
\hline
\end{tabular}

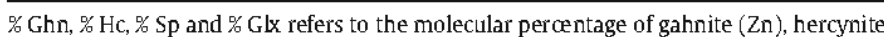
(Fe), spinel (Mg) and galaxite ( $\mathrm{Mn}$ ), respectively.

b.d.l.: below detection limit.

Mineral abbreviations are after Kretz (1983).

ata obtained by EPMA (wt.\%) is converted into ppm.
Al-Be-Zn accessory minerals is listed in Supplementary Tables 1 to 3 , including the correspondent detection limits. In some samples, beryl was analyzed on thin section ( $33 \mu \mathrm{m}$-thick); in these cases, however, the time of analysis was long enough for the detection and the acquisition of reliable trace element counts. During the time-resolved analysis of minerals, the contamination from inclusions, fractures and zones of different composition was detected by monitoring several elements and integrating only the relevant part of the signal. The counting time for one analysis was typically $90 \mathrm{~s}$ ( $36 \mathrm{~s}$ measuring gas blank to establish the background and $54 \mathrm{~s}$ for the remainder of the analysis). The repetition rate of the laser was $10 \mathrm{~Hz}$, with a fluence of approximately $3 \mathrm{~J} \cdot \mathrm{cm}^{-2}$. Spot size varied between 25 and $50 \mu \mathrm{m}$ in diameter, commonly using an aperture of $30 \mu \mathrm{m}$. The NIST 612 and BCR-2G glass standards were used to calibrate relative element sensitivities for the mineral analyses and to determine accuracy. Each analysis was normalized to $\mathrm{SiO}_{2}$ (K-feldspar, plagioclase, muscovite, biotite, cordierite, and beryl) or $\mathrm{Al}_{2} \mathrm{O}_{3}$ (chrysoberyl and gahnite), using the concentrations determined by electron microprobe in the different minerals measured. LA-ICP-MS analyses of BCR-2G reference sample are listed in Supplementary Table 4. Precision is estimated to be between $2 \%$ and $8 \%$ for most of the analyzed trace elements. In general, accuracy is better than $86 \%$ for most of the elements, although some of them (B and Be) show slightly larger inaccuracies (Supplementary Table 4). REE mineral contents have not been included in the tables as they are generally below their detection limits or they have $\sum \mathrm{REE}<1.5 \mathrm{ppm}$, both in main and accessory minerals.

\section{Petrographic features}

\subsection{General features of the Belvis pluton}

The Belvis intrusion is composed of three different leucogranitic units, sharing a medium- to coarse-grained hypidiomorphic texture, and showing accessory amounts of biotite and cordierite (commonly pinnitized). Although most of the cordierite is altered, it seems to be a late crystallizing phase as it is found as allotriomorphic nodules (up to $1.5 \mathrm{~cm}$ ) which commonly include drop-like quartz grains, and occasionally sub-idiomorphic to allotriomorphic chrysoberyl and beryl crystals. The major minerals in all facies are quartz (sub-idiomorphic to allotriomorphic grains included in other major minerals or forming individual to polycrystalline big crystals), plagioclase (mostly subidiomorphic polysynthetic twinned crystals), and K-feldspar (most of them late allotriomorphic perthitic crystals).

There are no sharp contacts between the distinguished granite units. Each facies seems to intrude in a short, probably coetaneous, time span, so that most of the exposed contacts are difficult to delimitate. The central and most intemal granite unit (CU) consists of a medium- to coarsegrained leucogranite with biotite $\geq$ muscovite and with a magmatic foliation defined by linear arrays of micas ( \pm sillimanite) parallel to the pluton shape. Occasionally it is possible to recognize extensional micro-shear bands, probably related to the pluton emplacement. Although the intemal unit is more biotitic when compared to other Belvis granitic facies, both micas are present in almost accessory amounts. Other accessory phases are altered cordierite, tourmaline (not only compositionally dravite, mostly replacing biotite crystals, but also as allotriomorphic grains included in other main minerals), brownish to colourless (Fe-Mn-F)-rich apatite, sillimanite (fibrolite associated with muscovite and/or biotite, or included as small needles or, more scarcely, as prisms in quartz, feldspars, muscovite and tourmaline), monazite and zircon. The high modal abundance of quartz, K-feldspar and plagioclase (92\%) gives this unit a light white colour. This central leucogranitic unit is the only one that contains small micaceous aggregates ( $<2 \mathrm{~cm}$ ) and scarce meta-igneous xenoliths (up to $40 \mathrm{~cm}$ ). This facies presents small biotite-rich pegmatitic patches (up to $3 \mathrm{~cm}$ ) or thin tourmaline-rich micropegmatitic veinlets, and also some cordierite-bearing aplitic veins parallel to the granite structure. These 
latter veins contain sub-idiomorphic to allotriomorphic chrysoberyl and idiomorphic to allotriomorphic beryl crystals as accessory phases (Fig. 1A). Although these minerals do not appear in the host granite unit, their presence in these granitic segregations confirms their magmatic origin.

The intermediate unit (IU) consists of a two mica medium- to coarse-grained leucogranite with muscovite $\geq$ biotite. Mica crystals are generally more idiomorphic and bigger (1-2 mm) than those from the central unit. Biotite appears in accessory amounts, whereas muscovite is one of the main magmatic phases. Other accessory phases are tourmaline (schorl, allotriomorphic grains included in biotite and quartz), cordierite (altered to mica aggregates or pinnite), sillimanite (mostly fibrolite variety included in primary muscovite and quartz or associated to biotite rims), (Fe-Mn-F)-rich apatite, (Nb-Ta)-rutile, zircon, U-rich monazite ( $\mathrm{UO}_{2}$ up to $23 \mathrm{wt} \%$ ) and U-rich xenotime ( $\mathrm{UO}_{2}$ up to 3 wt.\%) (Orejana et al., 2012; Pérez-Soba et al., 2009; Pérez-Soba et al, submitted for publication).

The external or border unit (BU), a coarse-grained muscovitic leucogranite (muscovite > biotite), displays the most heterogeneous mineral composition. Similar magmatic structures as those described in the CU are also present (occasional micro-shear bands). Muscovite and biotite grains can reach up to 3 and $1 \mathrm{~cm}$, respectively. Muscovite is not only found as primary sub-idiomorphic big crystals, but it is also present as late smaller allotriomorphic grains. Accessory phases include biotite, cordierite (in most cases altered, though this is the only unit which preserves fresh nodules), tourmaline (sub-idiomorphic small grains and allotriomorphic big crystals up to $3 \mathrm{~mm}$, with a rossmaniteschorl-dravite composition), (Fe-Mn-F)-rich apatite, sillimanite

Table 5

Representative major (wt.\%) and trace-element composition (ppm) of chrysoberyl (Chb) and beryl (Brl) from the Belvís granites.

\begin{tabular}{|c|c|c|c|c|c|c|c|}
\hline \multirow[b]{2}{*}{ Sample } & \multicolumn{4}{|l|}{ Belvís BU } & \multicolumn{2}{|c|}{ Aplitic segregate in CU } & \multirow{2}{*}{$\frac{\text { Aplopegmatite }}{111545}$} \\
\hline & 111533 & 112114 & 111533 & 112114 & 112109 & 112109 & \\
\hline Mineral & Chb & Cht & Brl & $\mathrm{Brl}$ & Chb & Brl & Cht \\
\hline \multirow[t]{2}{*}{ Analysis } & 37 & 11 & $12^{\prime}$ & 91 & 133 & 101 & 62 \\
\hline & Included in Qtz & Included in Crd & Included in Qtz & Included in altered $\mathrm{Crd}$ & Included in $Q t z$ & Included in Kfs & Included in Qtz \\
\hline $\mathrm{SiO}_{2}$ & 0.02 & 0.04 & 65.95 & 65.16 & 0.02 & 66.21 & 0.11 \\
\hline $\mathrm{TiO}_{2}$ & 0.11 & 0.23 & 0.00 & 0.00 & 0.54 & 0.00 & 0.02 \\
\hline $\mathrm{Al}_{2} \mathrm{O}_{3}$ & 78.63 & 80.36 & 18.54 & 18.08 & 78.26 & 18.40 & 79.14 \\
\hline FeO & 0.55 & 0.55 & 0.30 & 0.41 & 0.44 & 0.16 & 0.27 \\
\hline MnO & 0.00 & 0.00 & 0.02 & 0.00 & 0.01 & 0.01 & 0.01 \\
\hline $\mathrm{MgO}$ & 0.00 & 0.00 & 0.10 & 0.13 & 0.02 & 0.10 & 0.01 \\
\hline $\mathrm{CaO}$ & 0.60 & 0.01 & 0.01 & 0.01 & 0.03 & 0.01 & 0.01 \\
\hline $\mathrm{Na}_{2} \mathrm{O}$ & 0.02 & 0.60 & 0.22 & 0.34 & 0.02 & 0.21 & 0.03 \\
\hline $\mathrm{K}_{2} \mathrm{O}$ & 0.00 & 0.00 & 0.02 & 0.02 & 0.01 & 0.60 & 0.03 \\
\hline $\mathrm{Cr}_{2} \mathrm{O}_{3}$ & 0.02 & 0.04 & 0.04 & 0.00 & 0.04 & 0.60 & 0.00 \\
\hline Total & 79.33 & 81.23 & 99.83 & 99.72 & 79.38 & 99.83 & 79.60 \\
\hline $\mathrm{BeO}^{\mathrm{a}}$ & 19.32 & 21.10 & 15.76 & 15.57 & 18.96 & 15.88 & 19.93 \\
\hline \multicolumn{8}{|c|}{ No. of ions in formula } \\
\hline Si & 0.00 & 0.00 & 5.84 & 5.83 & 0.00 & 5.85 & 0.00 \\
\hline $\mathrm{Ti}$ & 0.60 & 0.60 & 0.00 & 0.00 & 0.01 & 0.60 & 0.00 \\
\hline Al & 1.99 & 1.96 & 1.93 & 1.91 & 2.00 & 1.92 & 1.97 \\
\hline $\mathrm{Fe}$ & 0.01 & 0.01 & 0.02 & 0.03 & 0.01 & 0.01 & 0.01 \\
\hline $\mathrm{Mn}$ & 0.00 & 0.60 & 0.00 & 0.00 & 0.60 & 0.60 & 0.00 \\
\hline $\mathrm{Mg}$ & 0.00 & 0.00 & 0.01 & 0.02 & 0.00 & 0.01 & 0.00 \\
\hline $\mathrm{Ca}$ & 0.00 & 0.00 & 0.00 & 0.00 & 0.00 & 0.00 & 0.00 \\
\hline $\mathrm{Na}$ & 0.00 & 0.00 & 0.04 & 0.06 & 0.00 & 0.04 & 0.00 \\
\hline $\mathrm{K}$ & 0.60 & 0.00 & 0.00 & 0.00 & 0.60 & 0.00 & 0.00 \\
\hline $\mathrm{Cr}$ & 0.60 & 0.00 & 0.00 & 0.00 & 0.60 & 0.00 & 0.00 \\
\hline $\mathrm{Be}$ & 1.00 & 1.05 & 3.35 & 3.36 & 0.99 & 3.37 & 1.04 \\
\hline $8 \mathrm{BeO}$ & 52.03 & 51.54 & 33.00 & 32.81 & 49.68 & 33.11 & 51.33 \\
\hline $\mathrm{g}_{\mathrm{a}} \mathrm{A}_{2} \mathrm{O}_{3}$ & 47.95 & 48.42 & 9.52 & 9.44 & 50.30 & 9.41 & 48.67 \\
\hline$y \mathrm{SiO}_{2}$ & 0.02 & 0.04 & 57.47 & 57.74 & 0.03 & 57.48 & 0.00 \\
\hline \multicolumn{8}{|c|}{ LA-ICP-MS trace-element analyses } \\
\hline $\mathrm{Ij}$ & b.d.1. & b.d.l. & 203 & 313 & b.d.1. & 195 & b.d.l. \\
\hline $\mathrm{Be}$ & 69,600 & 76,000 & 56,800 & 56,100 & 68,300 & 57,200 & 71,800 \\
\hline $\mathrm{B}$ & 104 & 13.3 & b.d.l. & b.d.l. & b.d.1. & b.d.1. & 10.5 \\
\hline Sc & b.d.1. & b.d.l. & 3.68 & 5.46 & b.d.1. & 3.64 & b.d.l. \\
\hline V & 1.55 & 11.7 & 1.94 & b.d.l. & 1.72 & b.d.1. & 0.35 \\
\hline $\mathrm{Co}$ & b.d.1. & b.d.l. & 14.9 & b.d.l. & b.d.1. & 0.2 & 0.48 \\
\hline $\mathrm{Zn}$ & b.d.1. & 4.75 & 193 & 120 & b.d.1. & 138 & b.d.l. \\
\hline $\mathrm{Rb}$ & b.d.l. & b.d.l. & 32.9 & 22.4 & b.d.1. & 19.1 & b.d.l. \\
\hline $\mathrm{Sr}$ & b.d.l. & b.d.l. & 0.29 & 0.16 & b.d.l. & b.d.l. & 0.04 \\
\hline Cs & b.d.1. & b.d.l. & 67.3 & 280 & b.d.1. & 705 & b.d.l. \\
\hline $\mathrm{Zr}$ & 0.42 & b.d.l. & 0.19 & b.d.l. & 0.22 & b.d.1. & b.d.l. \\
\hline Ta & 22.5 & 17.5 & b.d.l. & b.d.l. & 3.27 & 0.07 & 121 \\
\hline $\mathrm{Nb}$ & 30.6 & 1.36 & b.d.l. & b.d.l. & 1.33 & b.d.1. & 7.71 \\
\hline$W$ & 9.84 & b.d.l. & 0.18 & b.d.l. & 0.54 & b.d.1. & b.d.1. \\
\hline $\mathrm{Pb}$ & b.d.l. & b.d.l. & 1.55 & b.d.l. & b.d.1. & b.d.l. & b.d.l. \\
\hline $\mathrm{U}$ & b.d.l. & b.d.l. & 0.03 & 1.06 & b.d.1. & b.d.l. & b.d.l. \\
\hline
\end{tabular}

Structural formula calculated on basis on 4 oxygen atons (chrysoberyl) and on 18 oxygen atoms (beryl).

b.d.l.: below detection limit.

Mineral abbreviations are after Kretz (1983).

a Data obtained by LA-ICP-MS (ppm) is converted into gr oxide. 
(needles and, occasionally, prisms included in the main minerals, including muscovite, and tourmaline), rutile, zircon, pale green U-rich monazite $\left(\mathrm{UO}_{2}\right.$ up to $20 \mathrm{wt} \%$ ) and U-rich xenotime $\left(\mathrm{UO}_{2}\right.$ up to 13 wt.\%) (Orejana et al., 2012; Pérez-Soba et al., 2009; Pérez-Soba et al., submitted for publication), and an exotic group of minerals uncommon in granites, such as gahnite ( $\mathrm{Zn}$-spinel), beryl, chrysoberyl and a great variety of late to secondary ( $\mathrm{Al}-\mathrm{Fe}-\mathrm{Mn}-\mathrm{Ca}$ )-rich phosphates, such as emstite $\left(\mathrm{Mn}^{2+}{ }_{0.5} \mathrm{Fe}^{3+}{ }_{0.5} \mathrm{Al}\left(\mathrm{PO}_{4}\right)(\mathrm{OH})_{1.5} \mathrm{O}_{0.5}\right)$, vivianite $\left(\mathrm{Fe}^{2+}{ }_{3}\left(\mathrm{PO}_{4}\right)_{2} \cdot 8\left(\mathrm{H}_{2} \mathrm{O}\right)\right)$ and crandallite $\left(\mathrm{CaAl}_{3}\left(\mathrm{PO}_{4}\right)_{2}(\mathrm{OH})_{5} \cdot \mathrm{H}_{2} \mathrm{O}\right)$. In sectors where gahnite, beryl and chrysoberyl appear, tourmaline is not present.

The aplopegmatitic dike complex also presents some Zn-rich or Berich accessory phases, such as gahnite and chrysoberyl. Beryl is absent in the whole studied aplopegmatites (Fig. 1A). Some of these dikes occasionally present gamet and altered cordierite nodules, dispersed tourmaline crystals and (Al-Fe-Mn)-rich phosphates, similarly to the Belvís $\mathrm{BU}$, and muscovite and biotite are always accessory phases.
Sillimanite is present as fibrolitic or prismatic crystals included in the main minerals or associated to the chrysoberyl and gahnite rims.

\subsection{Gahnite, beryl and chrysoberyl characteristics}

\subsubsection{Gahnite}

Gahnite crystals are found in the BU and in the aplopegmatitic dikes (Fig. 1A). Gahnite from the BU leucogranite is idiomorphic to sub-idiomorphic (commonly up to $300 \mu \mathrm{m}$, but may reach up to $1 \mathrm{~mm}$ ), occasionally slightly fractured, included in plagioclase, K-feldspar or muscovite, and in contact with quartz (Fig. 2A, B). It is sometimes surrounded by a thin rim of (Mn, F, Zn, Fe)-rich apatite. Gahnite from the aplopegmatites has been found as subidiomorphic to allotriomorphic crystals with a variable size (from $<100 \mu \mathrm{m}$ to up to $1 \mathrm{~mm}$ in a pegmatite) and with the same textural relations as those described in the BU (Fig. 2C-F). It is occasionally very close to chrysoberyl, but never in direct contact with it (Fig. 2E).

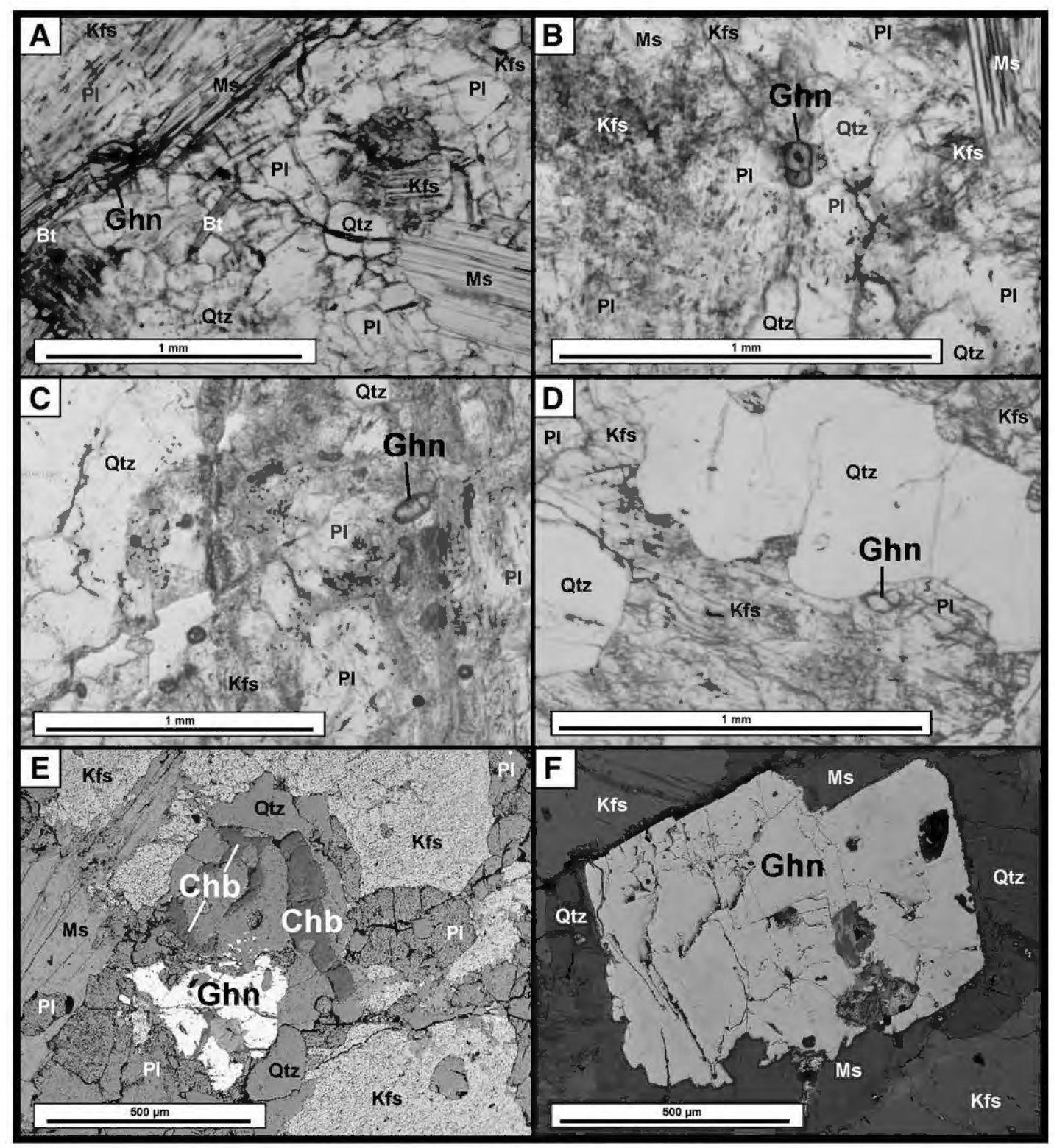

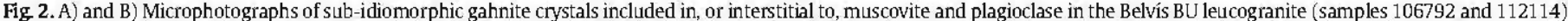

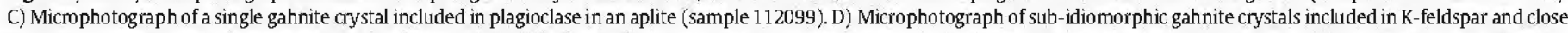

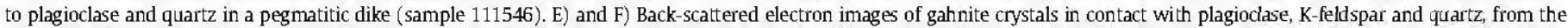
pegmatitic dike (sample 111545, close to allotriomorphic chrysoberyl; sample 111547, sub-idiomorphic large crystal). Mineral abbreviations are after Kretz (1983) and as in Fig. 1A 


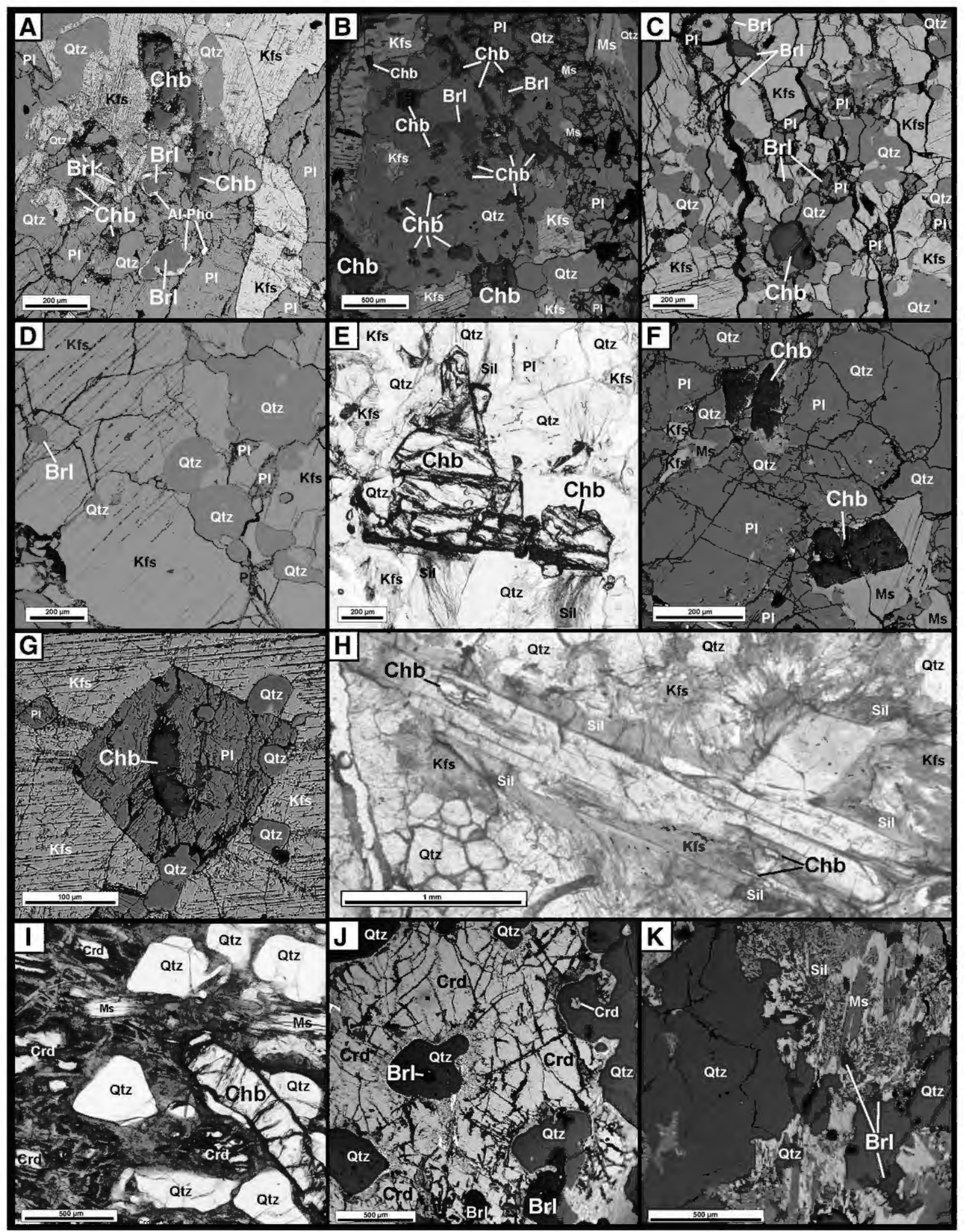

Fig. 3. A) and B) BSE images showing the association of chrysoberyl and beryl, in contact with plagioclase, K-feldspar or quartz in the BU leucogranite (samples 111533 and 112114 ). Note the thin rim of Al-rich phosphates (Al-Pho, bright BSE rim) surrounding some beryl crystals. C) and D) BSE images of the aplitic segregate of the Belvis CU (sample 112109) showing chrysoberyl and beryl grains included in quartz or K-feldspar. E) Microphotograph of a large chrysoberyl crystal included in quartz (in association with sillimanite) in the aplitic segregate (sample 112109). F) BSE image showing chrysoberyl crystals included in plagioclase or muscovite in an aplitic dike (sample 111601). G) BSE image of a small crystal of chrysoberyl included in plagioclase, both included in a large K-feldspar crystal in a pegmatite (sample 111546). H) Microphotograph of an altered large chrysoberyl crystal, apparently twined, surrounded by sillimanite, K-feldspar and quartz (pegmatitic dike, sample 111545). I) Microphotograph of an altered cordierite nodule of the Belvis BU leucogranite, including an allotriomorphic chrysoberyl crystal (sample 112114). J) Back-scattered electron image (BSE) of a partially altered cordierite nodule which includes quartz and beryl crystals (sample 112114). K) BSE image of a totally altered cordierite nodule with sub-idiomorphic to allotriomorphic beryl, quartz, muscovite and (Al-Fe)-rich phosphates (sample 112114). It is worth noting that although beryl is partially altered, it is always in contact with quartz. Mineral abbreviations are after Kretz (1983) and as in Fig. 1A. 


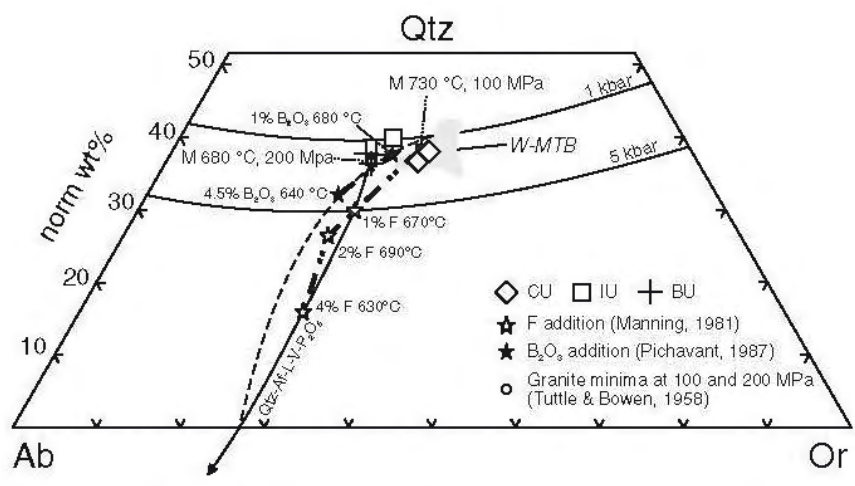

Fig 4. Qtz-Or-Ab temary diagram of the $\mathrm{H}_{2} \mathrm{O}$-saturated haplogranite system showing normative composition of the Belvis leucogranitic units compared to that the W-MTB granites (wt.\% components). Cotectics for $\mathrm{P}\left(\mathrm{H}_{2} \mathrm{O}\right)=1$ and $5 \mathrm{kbar}$ (solid lines) and minima for $\mathrm{P}\left(\mathrm{H}_{2} \mathrm{O}\right)$ between 1 and $4 \mathrm{kbar}$ and eutectic at $5 \mathrm{kbar}$ (dashed line) are taken from Luth et al. (1964). Granite minima at 100 and $200 \mathrm{MPa}$ (Tuttle and Bowen, 1958), "minimum melt compositions" and freezing point depression with the addition of fluorine (Manning, 1981) and boron (Pichavant, 1987), and the trend of compositional change of melts in the haplogranite system with phosphorus (solid arrow) are taken from London (1992a,b). Mineral abbreviations are after Kretz (1983).

\subsubsection{Chrysoberyl}

Chrysoberyl appears as sub-idiomorphic to allotriomorphic grains (up to $450 \mu \mathrm{m}$ ) in the BU, in the aplitic vein segregate of the CU and in some aplopegmatitic dikes (Fig. 1A). Chrysoberyl is commonly included in $\mathrm{K}$-feldspar, plagioclase, muscovite and quartz (Fig. 3A-H), and occasionally close to allotriomorphic beryl (Fig. 3A-C) or gahnite (Fig. 2E). In the BU, it is also included in partially altered cordierite (Fig. 3I). Although both beryl and chrysoberyl are relatively scarce, chrysoberyl occurs in a greater modal amount than beryl. The aplitic vein of the $\mathrm{CU}$ and the aplopegmatitic dikes also present larger (up to $3.5 \mathrm{~mm}$ ), apparently twinned, variably altered chrysoberyl crystals surrounded by quartz, mica aggregates, fibrolitic sillimanite and feldspars (Fig. 3E, H). In some cases, chrysoberyl crystals are also surrounded by a thin rim, or have small allotriomorphic inclusions, of secondary $\mathrm{Ca}-\mathrm{Al}-\mathrm{Fe}-\mathrm{Mn}-(\mathrm{Be}$ ?) phosphates.

\subsubsection{Beryl}

In contrast to chrysoberyl, beryl has not been observed in most of the samples where gahnite appears. The samples in which beryl has been found are those from the BU and the aplitic segregate in the $\mathrm{CU}$ (Fig. 1A). Beryl appears commonly as sub-idiomorphic to allotriomorphic colourless crystals (up to $120 \mu \mathrm{m}$ ), though scarce idiomorphic grains are also found (Fig. 3D). It is commonly included in plagioclase (Fig. 3A, C), $\mathrm{K}$-feldspar (Fig. 3A, C, D) and quartz (Fig. 3B), though in the BU it is also included in partially to totally altered cordierite (Fig. 3B, C). The observed sharp contacts between beryl and quartz grains, both within unaltered and altered cordierite (Fig. 3J, K), indicate that both minerals crystallized in equilibrium. In the $\mathrm{BU}$, scarce beryl crystals included in plagioclase are surrounded by a thin rim of Al-rich phosphates (crandallite; Fig. 3A).

\section{Whole-rock geochemistry}

All the studied Belvís granitic units have peraluminous character $(A C N K>1.2)$ and S-type affinity (Villaseca et al., 2008). When compared to other granitic bodies belonging to the western segment of the Montes de Toledo batholith, the Belvís pluton is one of the most felsic and evolved granites ( $\mathrm{SiO}_{2}$ up to $74.5 \mathrm{wt} \%$ ). In the A-B diagram (Debon and Le Fort, 1983; modified by Villaseca et al, 1998; not shown here), the samples from the Belvís pluton fall into the highly felsic peraluminous field $(\boldsymbol{P})$, whereas samples from other intrusions follow decreasing $\mathrm{Al}$ and $(\mathrm{Fe}+\mathrm{Mg}+\mathrm{Ti}$ ) trends from the highly to the moderately peraluminous ( $h \mathrm{P}$ to $\mathrm{mP}$ ) fields, and finally to the $f \mathrm{P}$ field in the more evolved facies (see Fig. 7 of Villaseca et al., 2008). All granites from the W-MTB (including Belvís) plot close to the granite minima in the Qtz-Or-Ab normative diagram, with $\mathrm{P}\left(\mathrm{H}_{2} \mathrm{O}\right)$ between 100 and $200 \mathrm{MPa}$ (Fig. 4). The Belvís pluton is depleted in $\mathrm{FeO}_{\mathrm{t}}, \mathrm{MgO}$, $\mathrm{TiO}_{2}$ and $\mathrm{CaO}$ when compared to the W-MTB granitoids, whereas it is highly enriched in $\mathrm{Na}_{2} \mathrm{O}$ and $\mathrm{P}_{2} \mathrm{O}_{5}$ (Fig. 5). These leucogranites are also depleted in some trace elements ( $\mathrm{Sc}, \mathrm{V}, \mathrm{Cr}, \mathrm{Zn}, \mathrm{Ba}, \mathrm{Th}, \mathrm{Pb}, \mathrm{Zr}, \mathrm{Hf}, \mathrm{Y}$ and REE; Fig. 6; Table 1; Villaseca et al., 2008). However, they show the highest Rb, Ta, Be U and Sn contents within the W-MTB (Fig. 6; Table 1; Villaseca et al., 2008). Moreover, Belvis is the pluton most depleted in REE of the W-MTB (Fig. 7).

Within the Belvís pluton, the $\mathrm{BU}$ displays lower $\mathrm{FeO}_{\mathrm{t}}, \mathrm{MgO}, \mathrm{TiO}_{2}, \mathrm{CaO}$ and $\mathrm{K}_{2} \mathrm{O}$ contents with respect to the intermediate and central units,
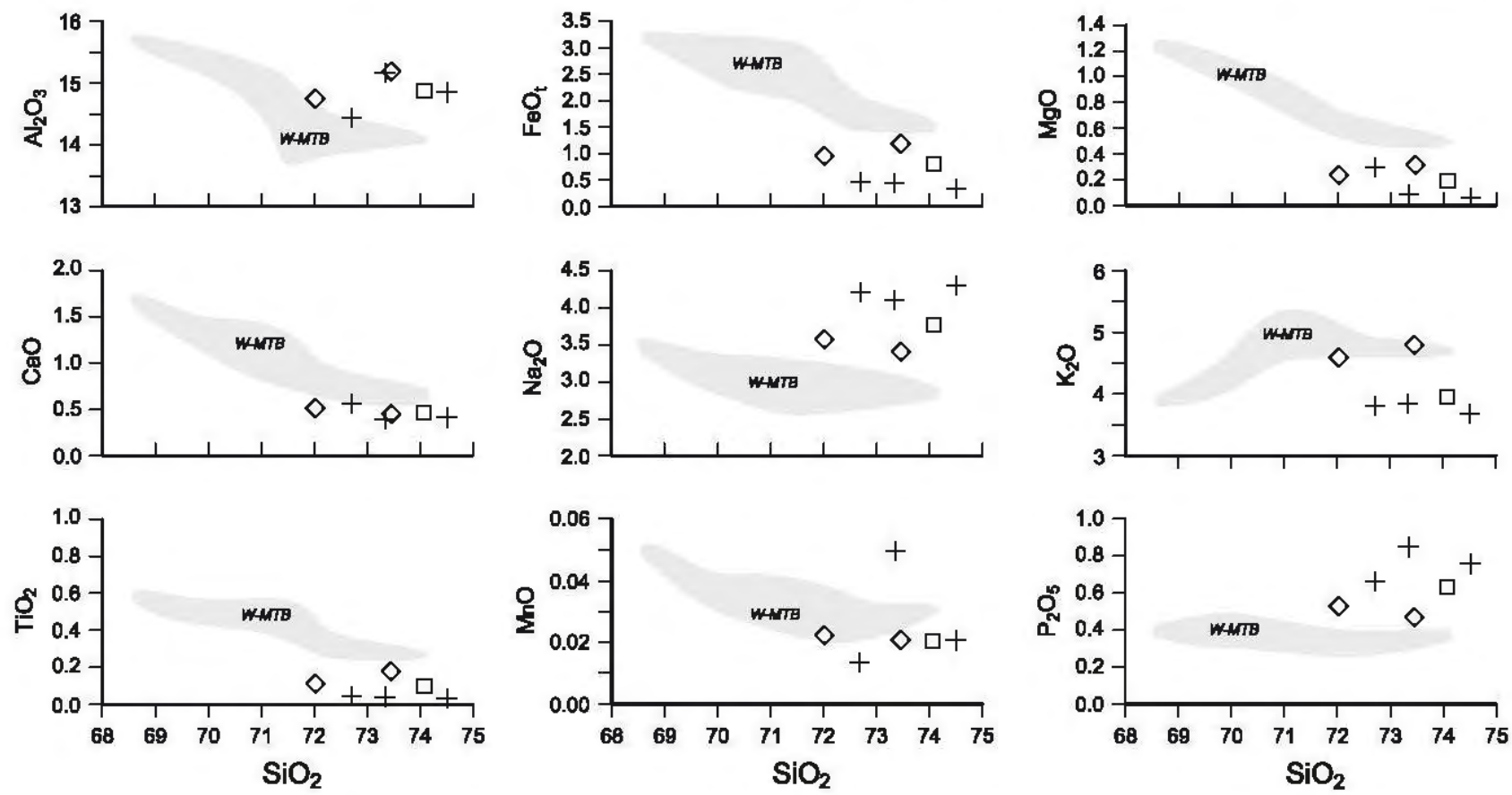

Fig. 5. Major element variation diagrams of the Belvís leucogranites. Shaded areas represent the compositional field of the W-MTB granitoids (Villaseca et al., 2008). 

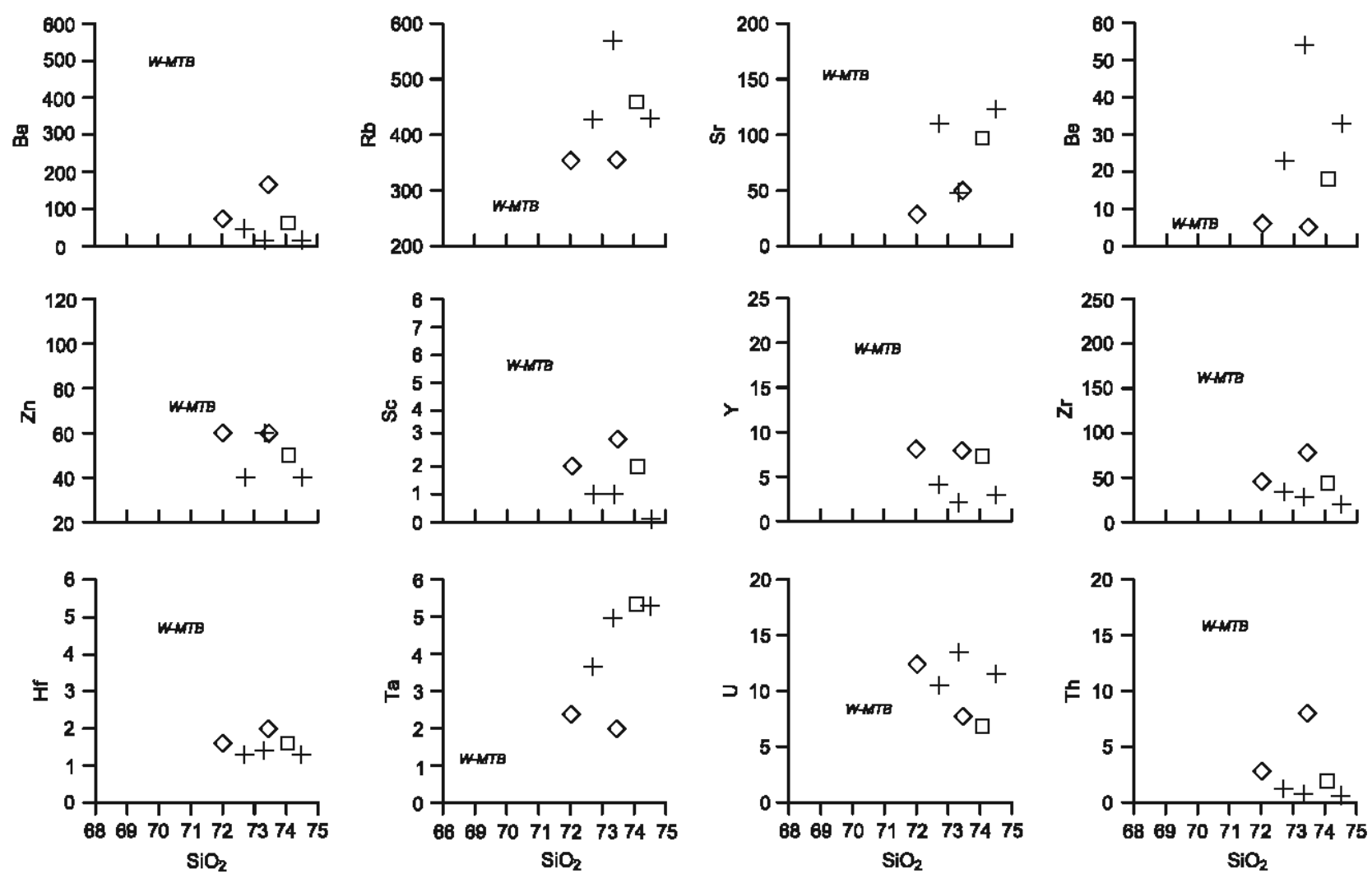

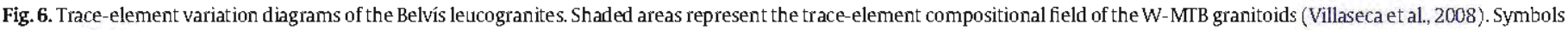
are as in Fig. 4.

thus defining a reverse zoned pluton. In contrast, the border unit has the highest $\mathrm{Na}_{2} \mathrm{O}$ and $\mathrm{P}_{2} \mathrm{O}_{5}$ contents (up to $4.3 \mathrm{wt} \%$ and 0.85 wt.\%, respectively; Fig. 5), more enriched than other perphosphorous and peraluminuus evolved granites of central Spain (e.g., the Pedrobernardo pluton; Bea et al., 1992). This external unit is mostly enriched in Rb, Sr, $\mathrm{Ta}, \mathrm{U}$ and $\mathrm{Be}$, when compared to the intermediate and central units (Fig. 6). The border and intermediate granitic units also show higher $\mathbf{F}$ and Li contents than the central leucogranite (Table 1). The chondritenormalized REE patterns of the Belvís leucogranitic units are sub-parallel and show decreasing REE contents and $(\mathrm{La} / \mathrm{Yb})_{n}$ ratios from the central to the external unit. The BU reaches the largest Eu negative anomaly of all granite units (Fig. 7).

It is worth noticing that, although the $\mathrm{Zn}$ whole-rock content of the Belvis samples is much lower than that from other plutonic

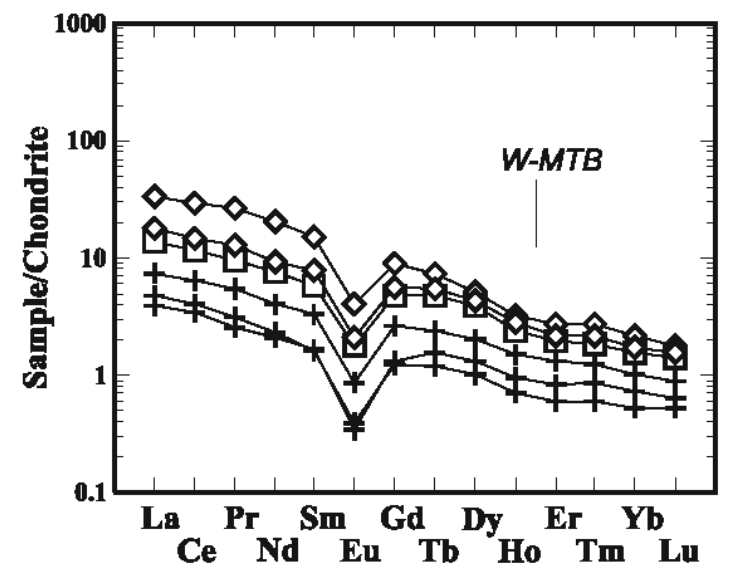

Fig. 7. Chondrite-normalized REE patterns of the Belvis units. Shaded area represents the REE composition of the W-MTB granitoids (taken from Villaseca et al., 2008). Normalization values are from Sun and McDonough (1989). Symbols are as in Fig. 4. bodies within the westem batholith, the $\mathrm{Zn} / \mathrm{Fe}_{\text {Total }}$ ratio is the highest in these samples, and it increases towards the most fractionated leucogranites of the $\mathrm{BU}\left(\mathrm{Zn} / \mathrm{Fe}_{\text {Total }}>0.01\right.$; Table 1$)$.

Although the bulk composition of the three units plots near the granite minimum in the Qtz-Or-Ab diagram (Fig. 4). samples from the $\mathrm{BU}$ plot beyond the eutectic composition towards a higher $\mathrm{Ab}$ component. This evolution occurs when increasing the fluxing components in the melt (London, 1992b). Hence, the presence of B (F) and $\mathrm{P}$ in the most external unit of the Belvís pluton promotes the reduction of the eutectic temperatures and an increase in the solubility limit of $\mathrm{H}_{2} \mathrm{O}$, reducing further the viscosity of this silicate melt (London, 1992b).

\section{Mineral chemistry}

Mean and representative major and trace-element composition of selected mineral phases from the granites described above are shown in Tables 2 to 5. In Supplementary Tables 1 to 3 are shown the whole trace-element dataset of gahnite, chrysoberyl and beryl.

\subsection{Major mineraIs}

\subsubsection{Feldspars}

K-feldspar from the CU (and its aplitic segregation) has the highest albite component $\left(\mathrm{Or}_{80-92} \mathrm{Ab}_{8-20}\right)$. In the IU the composition is more restricted and evolved ( $\left.\mathrm{Or}_{93-96} \mathrm{Ab}_{4-7}\right)$. K-feld spar from the $\mathrm{BU}$ and the aplopegmatitic dikes reach the highest or component, although displaying a wide compositional range ( $\mathrm{Or}_{83-100} \mathrm{Ab}_{0-17}$; Fig. 8A).

Plagioclase from the three units of the Belvis pluton, the aplitic segregation and the aplopegmatitic dikes has a Na-rich ( $A b>92 \mathrm{~mol} \%$ ) and F-rich (up to 0.16 wt.\%; Table 2) composition. Plagioclase from the $\mathrm{BU}$ is compositionally the most heterogeneous $\left(\mathrm{Ab}_{93-100} \mathrm{An}_{0-4} \mathrm{Or}_{0-3}\right.$; Fig. 8B). 

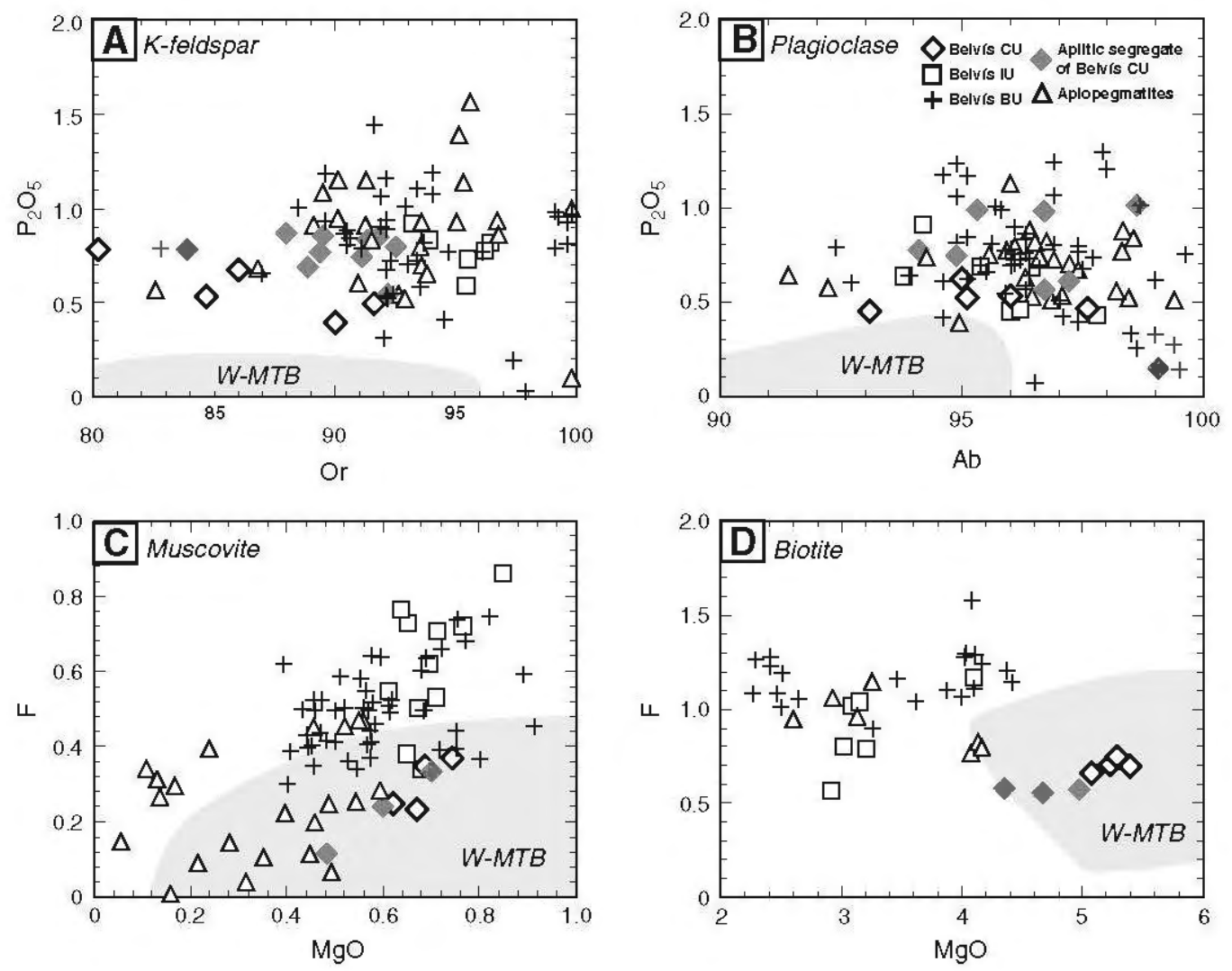

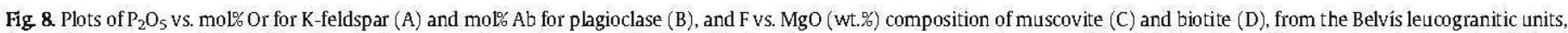

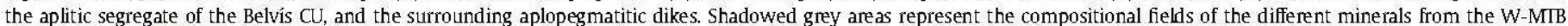
(Villaseca et al., 2008).

It is important to note that feldspars from all the Belvis units and the aplopegmatitic bodies show a high concentration of $\mathrm{P}_{2} \mathrm{O}_{5}$ (up to $1.6 \mathrm{wt} \%$ in $\mathrm{K}$-feldspar, and up to $1.3 \mathrm{wt} \%$ in plagioclase), much higher than feldspars from the rest of the western MTB granitic intrusions (Villaseca et al., 2008; Fig. 8A, B) and from other highly evolved peraluminous and perphosphorous plutons from the CIZ (e.g., the Pedrobernardo pluton; Bea et al., 1992). The most P-rich feldspars belong to the $\mathrm{BU}$ and the aplopegmatites (Table 2). $\mathrm{P}_{2} \mathrm{O}_{5}$ content in feldspars from the aplitic segregate is slightly higher than in those from its host CU leucogranite (Fig. 8A, B; Table 2).

Most trace elements in feldspars yield values below detection limits. However, the most evolved facies (BU and aplopegmatites) are characterized by an enriched composition in $\mathrm{Li}, \mathrm{Be}, \mathrm{B}, \mathrm{Zn}, \mathrm{Cs}, \mathrm{Sc}$, Nb and $\mathrm{Hf}$, when compared to the CU (Fig. 9; Table 2). On the contrary, Sr, Ba, Eu and $\mathrm{Pb}$ are proportionally more enriched in feldspars from the central unit (Fig. 9), although they are present in minor proportions (Table 2). Feldspars are slightly enriched in $\mathrm{Zn}$ in those granites that contain Beand Zn-rich phases (Fig. 9).

\subsubsection{Micas}

White micas have a homogeneous composition with predominance of the muscovitic component (Table 3). Muscovite from the CU has the highest $\mathrm{TiO}_{2}$ content (up to $0.8 \mathrm{wt} . \%$ ) and $\mathrm{Mg} \#$ ratios (from 0.5 to 0.6 ). On the contrary, $\mathrm{TiO}_{2}$ contents in muscovite from the IU and the $\mathrm{BU}$ are usually below $0.5 \mathrm{wt} . \%$, with $\mathrm{Mg} \#$ ranging from 0.4 to 0.5 , and from 0.3 to 0.5 , respectively. The highest $\mathrm{F}$ content in muscovite correspond to the BU and the IU (up to 0.75 wt.\% and 0.86 wt.\%, respectively), whereas those from the aplopegmatites and the $\mathrm{CU}$ yield the lowest $\mathrm{F}$ values (Fig. 8C). In general, F (and FeO) is positively correlated with $\mathrm{MgO}$, with a ratio of $1: 1$ (Fig. $8 \mathrm{C}$ ).

Fe-micas follow the annite-siderophyllite series. Most of the biotites from the Belvís pluton are Al-rich, with values above those from other
W-MTB granites (Villaseca et aL, 2008). MnO in biotite from the BU and the IU is higher than that from the $\mathrm{CU}$, whereas $\mathrm{Na}_{2} \mathrm{O}$ and $\mathrm{Mg \#}$ in biotite from this latter unit reach higher values (Table 3). $\mathrm{F}$ and $\mathrm{P}_{2} \mathrm{O}_{5}$ in biotite are also relatively enriched in the BU (up to $1.6 \mathrm{wt} . \%$ and 0.11 wt.\%, respectively; Fig. 8D).

Both micas are moderately to strongly enriched in $\mathrm{F}, \mathrm{Li}, \mathrm{Be}, \mathrm{Rb}, \mathrm{Nb}, \mathrm{Ta}$ and $\mathrm{W}$ in the Belvis $\mathrm{BU}$ and in the aplopegmatites with respect to the $\mathrm{CU}$ (Fig. 9; Table 3), and relatively depleted in $\mathrm{Sr}, \mathrm{Ba}$, Cs (except in muscovite from the BU), Sc and $\mathrm{Pb}$ (Fig. 9; Table 3). Similarly to feldspars, micas from granites having ( $\mathrm{Zn}$; Be)-rich accessory phases show slightly higher Zn contents (Fig. 9).

\subsubsection{Cordierite}

Cordierite from the $\mathrm{BU}$ has the typical composition of magmatic cordierite, with high $\mathrm{Na}_{2} \mathrm{O}$ (up to 2.3 wt.\%), MnO (up to 1.2 wt.\%), FeO (up to $14.6 \mathrm{wt} \%$ ), and low Mgo (less than $2.5 \mathrm{wt} . \%$; Villaseca and Barbero, 1994; Pereira and Bea, 1994). No chemical differences have been found between cordierite that includes either chrysoberyl or beryl crystals. $\mathrm{Li}$ and $\mathrm{Be}$ are the trace elements showing the highest concentrations in cordierite (mean contents of 1906 and $3920 \mathrm{ppm}$ respectively), although other elements such as $\mathrm{Zn}$, Cs and Rb may show significant concentrations: mean values of 493, 338 and $138 \mathrm{ppm}$, respectively (Table 3 ).

\subsection{Al-rich accessory minerals: gahnite, chrysoberyl and beryl}

\subsubsection{Gahnite $\left(\mathrm{ZnAl}_{2} \mathrm{O}_{4}\right)$}

In general, gahnite displays a slightly heterogeneous composition, with the gahnite component ranging from 55 to $71 \mathrm{~mol} \%$ and the hercynite component from 29 to $45 \mathrm{~mol} \%$ (Fig. 10A). This is reflected in $\mathrm{Zn} / \mathrm{Fe}_{\text {Total }}$ ratios in the range 1.1-2.5 (Fig. 10C). Gahnite from a pegmatite dike shows the highest MgO contents (up to $1.7 \mathrm{wt} \%$ ), 

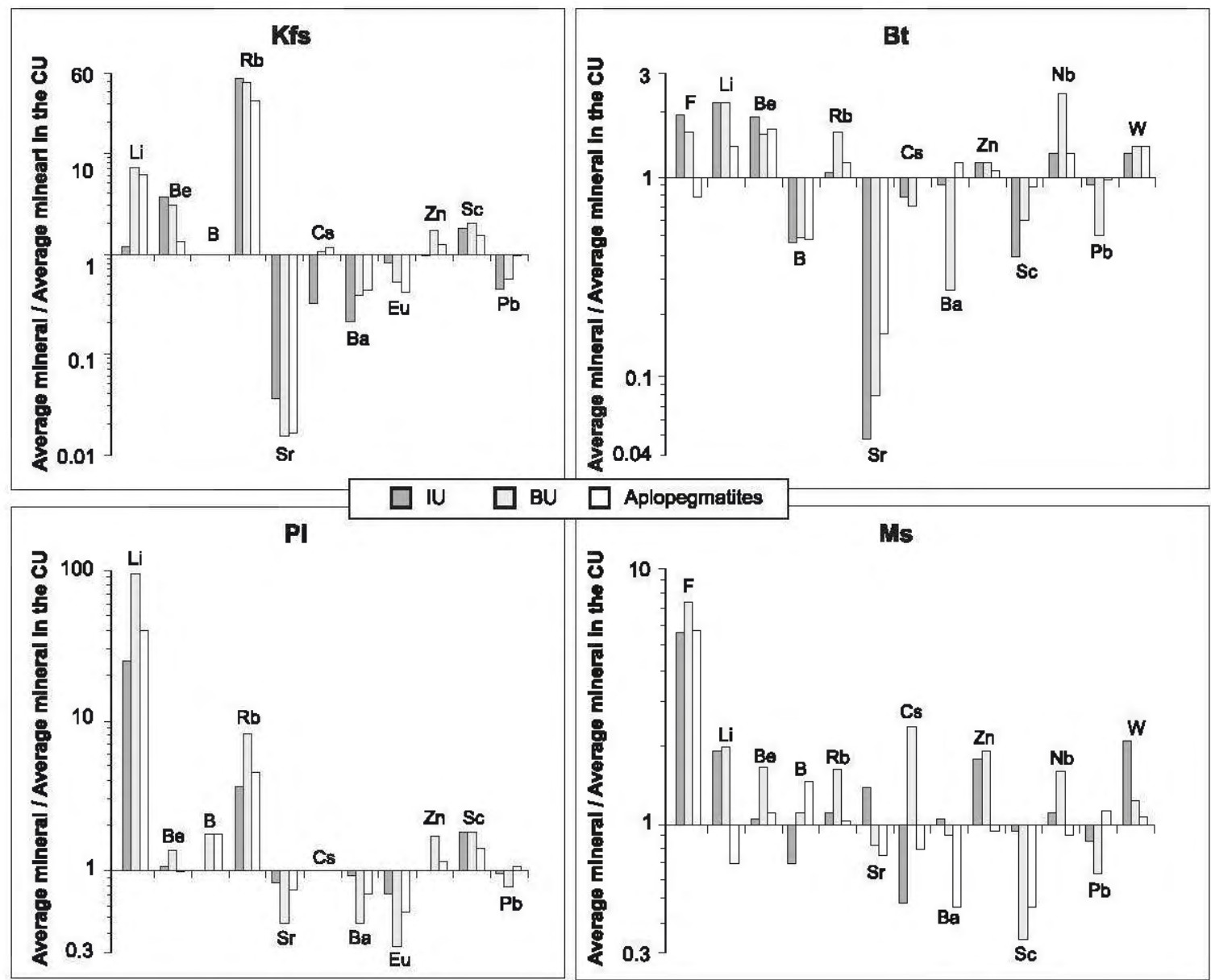

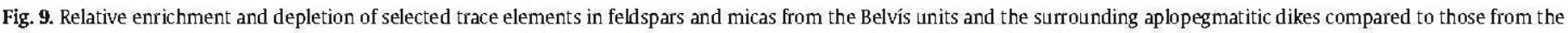
central unit. Chemical data are averaged mineral compositions (Tables 2 and 3). Mineral abbreviations are after Kretz (1983).

whereas the $\mathrm{FeO}$ and $\mathrm{MnO}$ concentrations are similar to those from other samples (Fig. 10A-C). This Mg enrichment is reflected in its higher spinel molecular component (up to $7.6 \mathrm{~mol} \%$ versus up to $2.6 \mathrm{~mol} \%$ in other gahnite grains; Fig. 10A; Table 4). Gahnite crystals found in other aplitic dikes have similar composition to those from the BU (Fig. 10A-C). Gahnite usually displays a slight chemical zonation characterized by an increase of $\mathrm{Mg}$ content with decreasing Mn concentration and $\mathrm{Zn} / \mathrm{Fe}_{\text {Total }}$ ratio from core to rim (Fig. 10C). The opposite chemical zoning is found in gahnite from the pegmatite (Fig. 10C).

Gahnite from Belvís granites enlarges the previously known igneous field towards higher Fe contents (higher hercynite component; Fig. 10A, B). Furthermore, gahnite from the Belvís pegmatite also increases the igneous field towards slightly higher $\mathrm{Mg}$ contents (higher spinel component).

Gahnite shows significant Li, Be and Co contents (Table 4; Supplementary Table 1). In fact, the Be concentration is higher than in most of the other granite mineral phases (e.g., K-feldspar, plagioclase and biotite), but similar to that of muscovite and clearly lower than in cordierite (Tables 2-4). Gahnite from the BU has a wide range of traceelement composition (Table 4), having the highest concentrations of $\mathrm{Li}$ (up to $182 \mathrm{ppm}$, almost doubling the values from the other gahnites) and Be (from 23.1 to $34.7 \mathrm{ppm}$; Table 4; Supplementary Table 1). In the case of $\mathrm{Co}$, gahnite from the pegmatitic dike yields the highest concentrations (up to $41.6 \mathrm{ppm}$ ).

\subsubsection{Chrysoberyl ( $\left.\mathrm{BeAl}_{2} \mathrm{O}_{4}\right)$}

Chrysoberyl from the Belvís BU has FeO contents ranging from 0.44 to $0.60 \mathrm{wt} . \%$, much lower than those from metamorphic rocks (2.5 to 3.2 wt.\%; Downes and Bevan, 2002) or metamorphosed pegmatites
(1.79 wt.\%; Franz and Morteani, 1984), and slightly lower than in granitic pegmatites ( 0.67 to 1.3 wt.\%; González del Tánago, 1991; Soman and Nair, 1985; Fig. $11 \mathrm{~A}$ ). $\mathrm{TiO}_{2}$ content varies from 0.05 to $1.71 \mathrm{wt} . \%$, whereas the $\mathrm{Cr}_{2} \mathrm{O}_{3}$ content is almost negligible (up to 0.06 wt.\%; Table 5). These $\mathrm{TiO}_{2}$ concentrations are higher than those reported in granitic pegmatites from the available literature (Fig. 11B). On the other hand, chrysoberyl in metamorphic rocks usually has $\mathrm{TiO}_{2}$ concentrations below detection limits and $\mathrm{Cr}_{2} \mathrm{O}_{3}$ contents up to 1.36 wt.\% (e.g., Downes and Bevan, 2002).

Similar to gahnite, chrysoberyl does not accept many trace elements in its structure, but it can contain minor amounts of Ta, B, Nb, V, Zn, Li, Sc, $\mathrm{Co}, \mathrm{Zr}, \mathrm{W}, \mathrm{U}(<1 \mathrm{ppm})$ and REE ( $<1 \mathrm{ppm})$ (Supplementary Table 2). In general, Be contents measured in chrysoberyl are higher than those obtained in beryl from the same sample (Supplementary Table 3). Chrysoberyl reaches its maximum trace-element concentrations in the BU leucogranite (similarly to other mineral phases), with Ta up to $273 \mathrm{ppm}, \mathrm{B}$ up to $104 \mathrm{ppm}$ and Nb up to $60 \mathrm{ppm}$ (Table 5; Supplementary Table 2). In this unit the chrysoberyl Be and Li contents are also higher than in chrysoberyl from the aplopegmatitic lithotypes (Table 5).

\subsection{3. $\mathrm{Beryl}\left(\mathrm{Be}_{3} \mathrm{Al}_{2} \mathrm{Si}_{6} \mathrm{O}_{18}\right)$}

The Beryl composition is relatively homogeneous, with $\mathrm{Na}_{2} \mathrm{O}$ and FeO contents ranging from 0.1 to 0.43 wt.\% and from 0.15 to $0.51 \mathrm{wt} . \%$, respectively (Fig. $11 \mathrm{C}$ ). The highest $\mathrm{Na}$ and $\mathrm{Fe}$ values correspond to beryl included in altered cordierite (Fig. 3K).

Contrary to chrysoberyl, the $\mathrm{B}$, Ta and $\mathrm{Nb}$ concentrations are negligible within beryl, whereas it hosts trace contents of $\mathrm{Li}, \mathrm{Zn}, \mathrm{Cs}$ and $\mathrm{Rb}$. Beryl from the BU contains higher concentrations of $\mathrm{Li}, \mathrm{Zn}$ and $\mathrm{Rb}$ and lower of $\mathrm{Cs}$ and Be when compared to beryl from the aplitic vein 

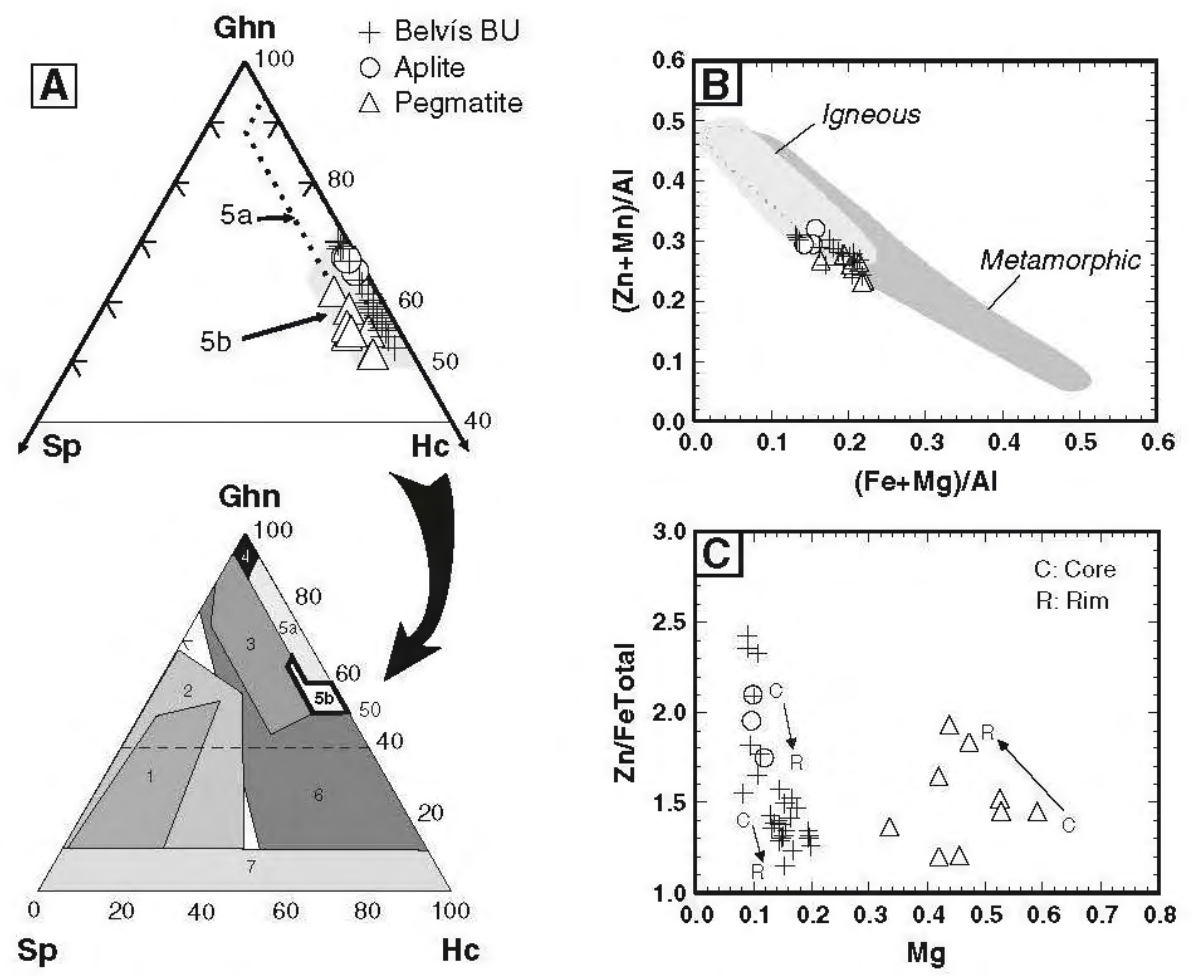

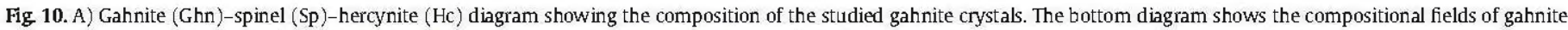

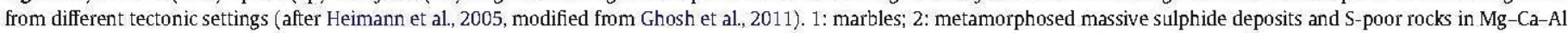

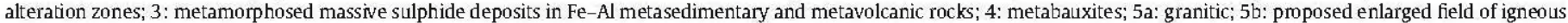

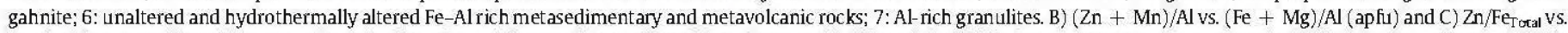

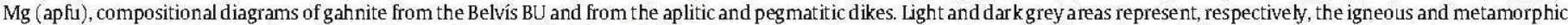

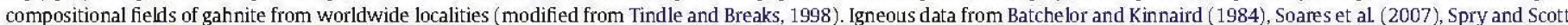

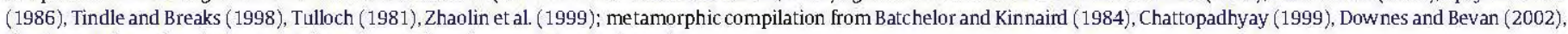
Ghosh et al (2011), Heimann et al. (2005), Spry (1987), Spry and Scott (1986).

(Table 5; Supplementary Table 3). In this latter segregate, the highest Cs contents correspond to a ( $\mathrm{Na}, \mathrm{Fe}$ )-rich beryl included in altered cordierite (Fig. 11D-F).

The general compositional trend followed by the Belvis beryl is equivalent to that described in other magmatic beryl, with a strong increase in Cs/Na values and low $\mathrm{Mg} / \mathrm{Fe}$ ratios (Fig. 11D). In highly evolved peraluminous pegmatites, beryl presents a negative correlation between Be and Li-Cs-Rb (tetrahedral type-2 substitutions according to Barton and Young, 2002). However, the Cs, Rb and Li contents in the studied beryl crystals are much lower than in those from Be- and Lirich pegmatites ( $\mathrm{Li}$ and $\mathrm{Cs}$ up to $3 \mathrm{wt} \%$ and $\mathrm{Rb}$ up to $447 \mathrm{ppm}$; Uher et al., 2010; Wise and Brown, 2010; Fig. 11E, F).

\section{Discussion}

\subsection{The Belvis reversely zoned pluton: a case of a highly evolved granitic} magma

The Belvis pluton is a highly felsic ( $\mathrm{SiO}_{2}>72 \mathrm{wt}$.\%) peraluminous $(A C N K>1.2)$ and perphosphoric $\left(\mathrm{P}_{2} \mathrm{O}_{5}\right.$ up to 0.85 wt.\%) fractionated granite. Its petrographic features, whole-rock composition and mineral chemistry allow the distinction of a reverse zoning, with the border unit characterized by the most leucocratic Fe-Mg-Ti-REE-poor facies, similarly to other reversely zoned granites: the Turtle pluton in SE California (Allen, 1992), the Castelo Branco pluton in Portugal (Antunes, 2008); the Říčany pluton in Czech Republic (Janoušek et al., 1997); and the Notch Peak granitic stock in Utah (Nabelek et al., 1986). Moreover, the external unit is enriched in highly incompatible elements and developed a mineral assemblage which includes many different accessory phases uncommon in granites (e.g., beryl, chrysoberyl, gahnite, U-rich monazite and xenotime, and (Al-Fe-Mn-Ca)-phosphates).

The Belvís BU leucogranite shows high $\mathrm{P}, \mathrm{F}, \mathrm{Li}, \mathrm{Rb}, \mathrm{Sn}, \mathrm{Cs}, \mathrm{Ta}, \mathrm{Be}$ and U contents (Fig. 5; Table 1; Villaseca et al., 2008). Correlatively, this unit has rock-forming minerals enriched in some incompatible elements when compared with those from the other Belvís units. In this regard, both feldspars and micas from the BU are comparatively entiched in $\mathrm{Li}, \mathrm{Be}, \mathrm{B}$ and $\mathrm{F}$, and some of them are slightly enriched in Rb, Cs, Sc and Zn (Fig. 9; Tables 2, 3). The above chemical differences might be indicative of a variable degree of crystal fractionation in each unit. This possibility is also reflected in the increase of $\mathrm{P}_{2} \mathrm{O}_{5}$ content in both $\mathrm{Na}$ - and $\mathrm{K}$-rich feldspars from the central unit (up to 0.6 and $0.8 \mathrm{wt} \%$, respectively) to the border unit (up to 1.3 and $1.4 \mathrm{wt} \%$, respectively; Fig. $8 \mathrm{~A}, \mathrm{~B}$ ). According to Kontak et al. (1996) and London (1992a), the P content of feldspar increases with the degree of granitic magma evolution, as also occurs in the whole-rock composition, favoured by the high peraluminous character of the melt.

A crystal fractionation model using trace elements which are mainly controlled by major minerals (e.g., Rb and Ba) has been applied. The parameters used are detailed in the caption to Fig. 12. The resulting evolution trends are in accordance with the chemical variation depicted by samples from the three Belvís units and the results support the contention that the IU and the BU may represent evolved melts derived by fractional crystallization (plagioclase $+\mathrm{K}$-feldspar + biotite + quartz) from an initial monzogranitic to granodionitic magma with a composition close to that of the CU. A fractionation degree in the range of $20-40 \%$ is required to explain the most evolved BU composition (Fig. 12). This does not imply that both the IU and BU granites are directly derived by fractional crystallization of the CU granite, but instead they likely represent differently evolved pulses from a deeper magma 


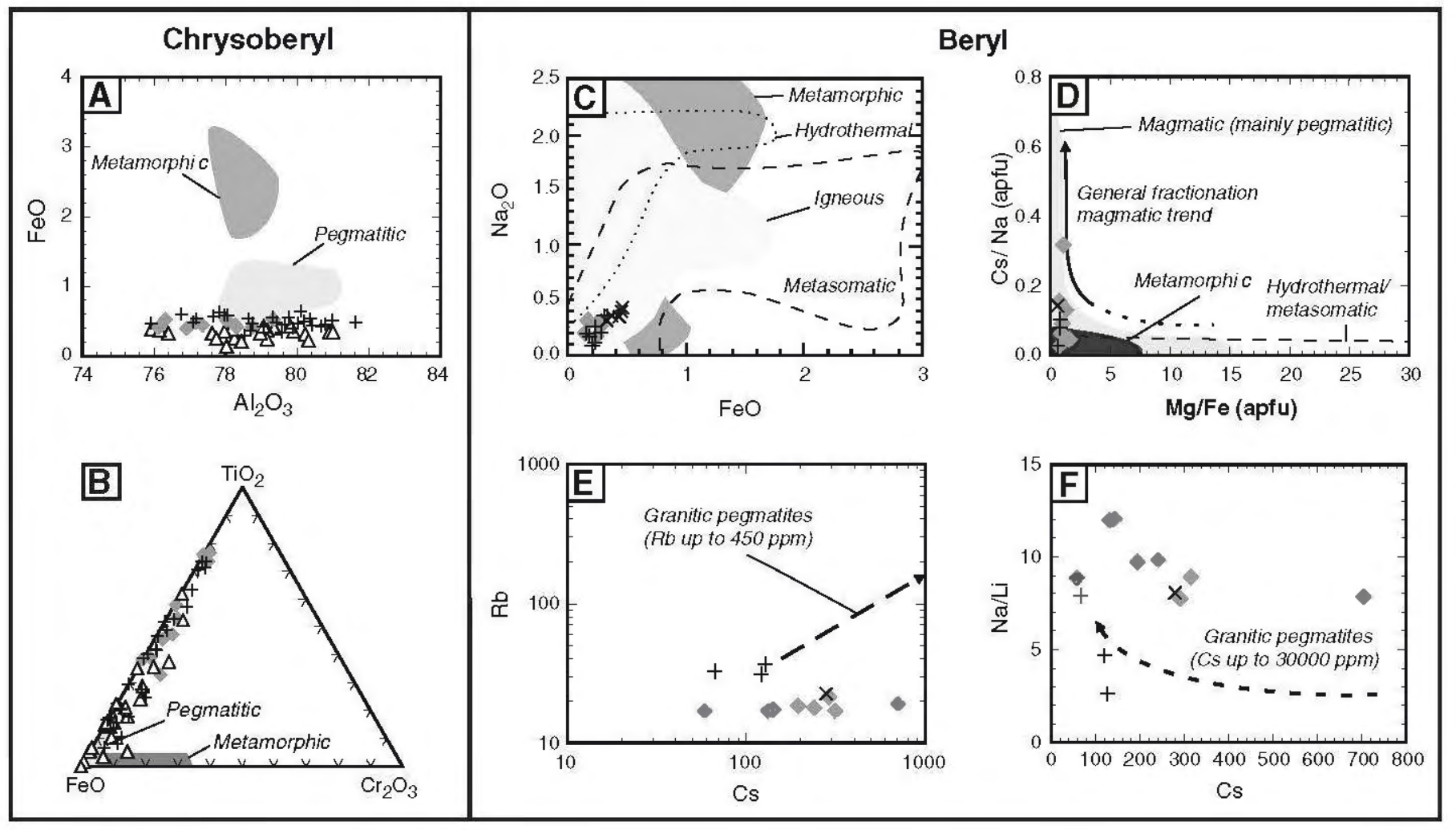

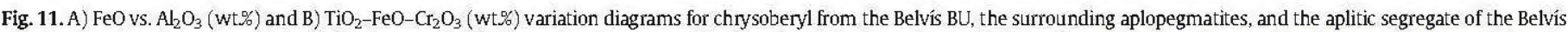

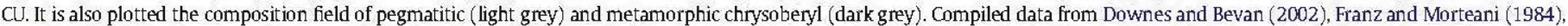

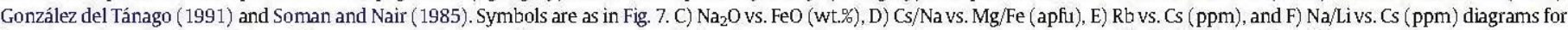

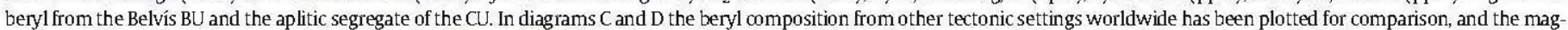

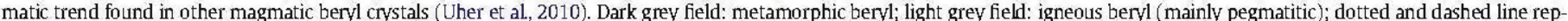

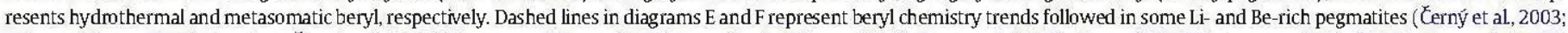

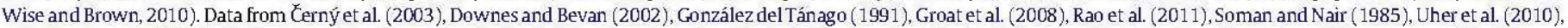
and Zhaolin et al (1999). Black crosses: beryl from the BU; black diagonal crosses: beryl included in altered cordierite (BU); grey diamonds: beryl from the aplitic segregate of the CU.

chamber with a composition similar to the less fractionated CU granite. The range of initial $\mathrm{Sr}-\mathrm{Nd}$ isotopic ratios between all the granite units $\left(\mathrm{Nd}_{300}\right.$ from -5.34 to $-6.18 ;\left({ }^{87} \mathrm{Sr} /{ }^{86} \mathrm{Sr}\right)_{300}$ mainly from 0.7170 to 0.7215 ; Table 1) suggests that they are derived from isotopically heterogeneous parental melts. At magma stagnation levels, physical (and fractional crystallization) processes are not sufficiently efficient to homogenize the marked initial isotope heterogeneity of the magma batches, and the isotopic signature of the Belvís units simply reflects the source-inherited heterogeneities (Clemens and Stevens, 2012).

The reverse zoning in granite intrusions has been widely attributed to several processes: i) flow segregation of mafic minerals towards the core; ii) reordering of an underlying and vertically stratified magma chamber by sequential emplacement of composite pulses (Allen, 1992; Antunes, 2008); iii) intrusion of a single magmatic pulse with major fractionation in the magma chamber before the final emplacement (Janoušek et al., 1997; Nabelek et al., 1986); and iv) discontinuous magma injection (Hecht and Vigneresse, 1999). We interpret the reverse zoning in the Belvis pluton to be the result of the emplacement of successive magmatic pulses which have previously evolved by fractional crystallization from a more primitive melt in a deeper magma chamber. The high concentration of volatile and fluxing components in the most evolved unit (BU), and therefore its lower density and viscosity, would promote its emplacement previous to the ascent of the other leucogranitic units (IU and CU). The sequential emplacement of slightly less evolved melts from the magma chamber gave rise to the reversely zoned pattern of the Belvís pluton (Fig. 1C).

The $\mathrm{BU}$ of the Belvis pluton shows similarities to beryl-rich granitic pegmatites, which have an affinity with the LCT ( $\mathrm{Li}-\mathrm{CS}-\mathrm{Ta}$ ) geochemical family of granitic pegmatites (Čemý, 1991). The bulk composition of these pegmatites also overlaps the granite minimum in the Qtz-Or-Ab system (Shearer et al., 1992). Černý (1991) describes these pegmatites as leucocratic, potassic and peraluminous, and associates their origin with granites formed by melting of undepleted metapelitic supracrustal rocks. Granites from the western MTB have been interpreted as derived from heterogeneous metasedimentary sources on the basis of wholerock and isotope geochemistry (Villaseca et al., 2008). In this regard, micas from the source might account for an initial enrichment of $\mathrm{Be}$ in the melt, as those minerals are the likely reservoir of most Be (Armbruster and Irouschek, 1983; Evensen and London, 2002, 2003). The perphosphoric character of these plutons has been interpreted as a possible chemical fingerprint inherited from P-rich metasedimentary source rocks (Villaseca et al., 2008), due to the high P contents observed in the W-MTB granites $\left(\mathrm{P}_{2} \mathrm{O}_{5}>0.3 \mathrm{wt} \%\right.$ ) when compared to other granite batholiths of the $\mathrm{CIZ}$ at similar differentiation values (e.g., $\mathrm{SiO}_{2}$ or ASI contents; see Figs. 8 and 13 from Villaseca et al., 2008). In any case, crystal fractionation processes also have lead to incompatible and volatile enrichment in highly felsic residual melts (Shearer et al., 1992), as occurs in the Belvis pluton.

\subsection{P-T conditions of granite crystallization}

The large mineral assemblage found in the Belvís BU (beryl, chrysoberyl, quartz, gahnite, cordierite, and sillimanite), is stable over a wide range of pressures and temperatures (see Barton, 1986; Barton and Young, 2002; Evensen and London, 2002; Spry, 1987; Spry and Scott, 1986).

As a first approach to constrain the temperature of magma crystallization of the Belvís units, we have used the zircon and monazite 


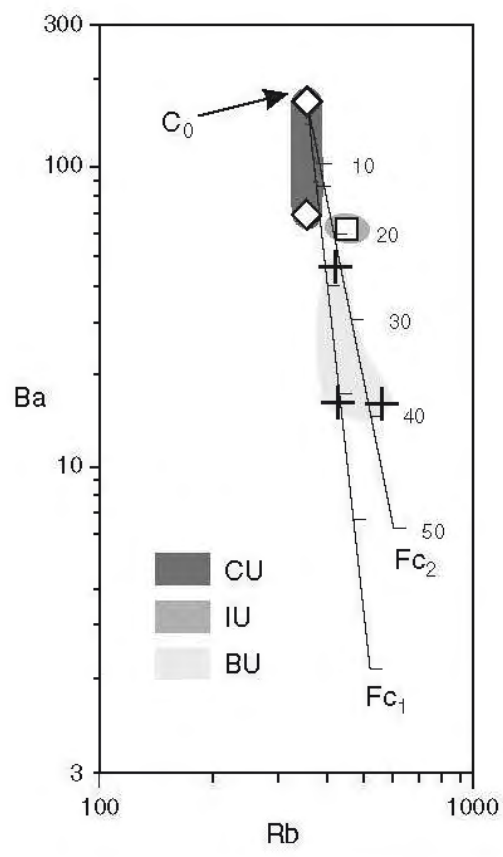

Fig 12. Plot of $\mathrm{Rb} v \mathrm{vs}$. $\mathrm{Ba}$ (in ppm) showing the results of a fractional crystallization model $\left(\mathrm{C}_{\mathrm{L}}=\mathrm{C}_{\mathrm{O}} * \mathrm{~F}^{\mathrm{D}-1 \mathrm{1})}\right.$ together with bulk-rock data from the Belvís granite units. The initial melt composition $\left(C_{0}\right)$ of $\mathrm{Rb}$ and $\mathrm{Ba}$ used in the modelling is $\mathrm{Ba}=167 \mathrm{ppm}$ and $\mathrm{Rb}=$ $355 \mathrm{ppm}$. The vectors represent the fraction of melt (tick-marks intervals of $10 \%$ ) starting from the initial composition described above. The model considers two evolution trends with the following modes of the fractionating minerals: $\mathrm{FC}_{1}=35 \% \mathrm{Pl}, 25 \% \mathrm{Kfs}, 10 \% \mathrm{Bt}$ and 30\% Qtz; and $\mathrm{FC}_{2}=50 \% \mathrm{Pl}, 20 \% \mathrm{Kfs}, 5 \% \mathrm{Bt}$ and $25 \% \mathrm{Qtz}$. Distribution coefficients of $\mathrm{Rb}$ and $\mathrm{Ba}$ in $\mathrm{K}$-feldspar, plagioclase and biotite for peraluminous felsic melts according to Icenhower and London (1995, 1996). Mineral abbreviations are after Kretz (1983). Symbols are as in Fig. 4.

saturation geothermometers (Montel, 1993; Watson and Harrison, 1983 ), which yield average decreasing values from the central (724 and $757^{\circ} \mathrm{C}$ ) to the border unit $\left(664\right.$ and $693^{\circ} \mathrm{C}$; Table 1$)$, in accordance with the Qtz-Or-Ab normative diagram (Fig. 4). The idiomorphic character of both accessory minerals (zircon and monazite), and their common presence as inclusions within biotite and feldspars and muscovite, respectively, suggests a magmatic origin and, therefore, crystallization in chemical equilibrium with the melt (Orejana et al., 2012).

In a second approach to the P-T crystallization conditions of the Belvís pluton, we consider both the granite mineral paragenesis and experimental studies on granitic rocks with similar composition. The presence of sillimanite included within the main minerals (including muscovite) and the large size and high $\mathrm{TiO}_{2}$ contents of muscovite point to a magmatic origin for the assemblage muscovite + sillimanite. Moreover, the presence of prismatic sillimanite inclusions in the main minerals of the surrounding aplopegmatitic complex further suggests its magmatic origin. In this regard, the temperature of crystallization of the Belvís granites should be below the upper limit of igneous muscovite, within the sillimanite stability field, and over the wet granite solidus (Johannes and Holtz, 1996; Fig. 13). Taking into account that the whole Belvís pluton has a highly-peraluminous character, we consider that the granite solidus curve is slightly depressed towards lower temperature conditions $\left(\mathrm{Al}_{2} \mathrm{O}_{3}\right.$-saturated granite solidus; Johannes and Holtz, 1996; curve 1 in Fig. 13). Although the Belvís BU granites plot in the $200 \mathrm{MPa} \mathrm{H}_{2} \mathrm{O}$ haplogranite eutectic of Tuttle and Bowen (1958) (Fig. 4), the estimated temperatures may be slightly lower considering that the Belvis pluton is a P- (F-) and presumably B-enriched melt (Manning and Pichavant, 1983) in comparison to typical granites. This is shown by the presence of F-rich phosphates and the local tourmalinization in the wall-rocks.

The crystallization of primary igneous muscovite in the Belvis pluton implies an increase in the stability field of muscovite (D'Amico et al., 1981; Villaseca et al., 2008). The empirical M' curve of D'Amico et al.

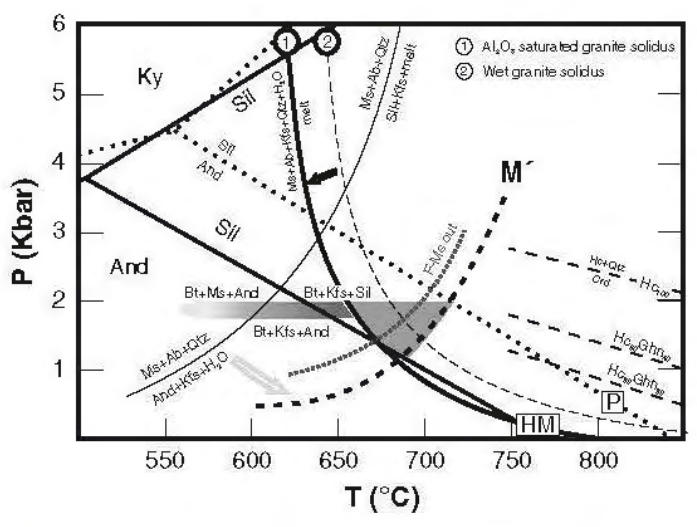

Fig. 13. P-T diagram showing the estimated crystallization conditions for the Belvis BU leucogranite (shaded area). Aluminium silicate stability field according to HM: Holdaway and Mukhopadhyay (1993), and P: Pattison (1992), using a $K_{\text {eq }}\left(\mathrm{X}_{\text {sill }} / \mathrm{X}_{\text {and }}\right)=1$ for the andal usite-sillimanite equilibrium after Kerrick and Speer (1988). Melting curve and reaction involving muscovite are taken from Johannes and Holtz (1996) (1: $\mathrm{Al}_{2} \mathrm{O}_{3}$-saturated granite solidus; 2 : wet granite solidus). $\mathrm{M}^{\prime}$ : stability reaction curve of muscovite for the reaction $\mathrm{Ms}+\mathrm{Ab}+\mathrm{Qtz}=\mathrm{Kfs}+\mathrm{Al}$-silicate $+\mathrm{H}_{2} \mathrm{O}$ /melt, according to D'Amico et al. (1981). F-Ms out: reaction curve of F-rich muscovite after Pichavant et al. (1988). Fe- $\mathrm{Zn}$ hercynite reactions from Montel et al. (1986), in terms of molecular proportion of hercynite (Hc) and gahnite (Ghn). The thick grey horizontal bar represents the estimated conditions of the contact metamorphism generated by the Belvis intrusion based on the mineral association found in the host-rocks. Mineral symbols are after Kretz (1983) and as in Fig. 1A.

(1981), based on cationic substitutions (mainly Ti and Na cations) in the muscovite structure, better describes the coetaneous crystallization of igneous muscovite together with cordierite, fibrolitic sillimanite, gahnite, chrysoberyl and beryl in a wider temperature range. The enlargement of the muscovite stability field co-existing with peraluminous melts due to minor cation substitution (mainly $\mathrm{F}$ ) was also stated by Pichavant et al. (1988) in Macusani peraluminous glasses (F-Ms out curve in Fig. 13), and evidenced in experimental studies in F-rich peraluminous systems (Lukkari and Holtz, 2007). The temperatures calculated with zircon and monazite saturation thermometry are in accordance with the thermal conditions constrained on the basis of sillimanite-muscovite stability and solidus position (Fig. 13).

In applying the andalusite-sillimanite equilibrium curve of Pattison (1992), the minimum pressure required for the crystallization of igneous muscovite and sillimanite should be about $2.5 \mathrm{kbar}$ for the temperatures calculated in the Belvís BU (in the range of 670 to $700{ }^{\circ} \mathrm{C}$; Fig. 12; Table 1). However, we suggest that pressures of crystallization equal or lower than $2 \mathrm{kbar}$ are more appropriate. The contact metamorphism induced by the Belvis intrusion in the surrounding Palaeozoic low-grade facies metasediments promotes the formation of $\mathrm{K}$-feldspar + sillimanite + biotite \pm cordierite near the contact, and biotite + andalusite + muscovite \pm cordierite \pm fibrolitic sillimanite in the outer metamorphic aureole. These mineral associations are characteristic of low-pressures ( $\leq 2 \mathrm{kbar}$; IGME, 1987) and temperatures between $575^{\circ}$ and $650^{\circ} \mathrm{C}$, quite close to those estimated for the Belvís intrusion (Fig. 12). Therefore, we suggest employing the aluminosilicate equilibrium curve of Holdaway and Mukhopadhyay (1993) which fits better with the estimated P-T conditions of the Belvis pluton emplacement and, consequently, allows the precipitation of igneous muscovite together with sillimanite at low pressures ( $<2 \mathrm{kbar})$ and temperatures $\left(<750^{\circ} \mathrm{C}\right)$, in accordance with the calculations shown in Table 1 (Fig. 13).

Experimental studies conducted on beryl-bearing pegmatites yielded crystallization P-T conditions between 600 and $720^{\circ} \mathrm{C}$ and about 2 kbar (Thomas et al., 2009, 2011), similar to our estimations. These conditions are also supported by the calculations of Montel et al. (1986), which show that a higher gahnite component in hercynitic spinel enlarges its stability field towards lower temperatures and pressures. The hercynite stability curve corresponding to a $50 \%$ of gahnite component would imply an upper pressure limit near $2 \mathrm{kbar}$ if it is 
extrapolated towards the $\mathrm{Al}_{2} \mathrm{O}_{3}$-saturated granite solidus within the calculated Belvís temperatures. Taking into account the high abundance of the gahnite component (55-71\%) in the Zn-spinel from the Belvís pluton, a fairly restricted $P-T$ space should be expected, with pressures likely to have been below $2 \mathrm{kbar}$ (Fig. 13).

The P-T conditions estimated for the Belvis $\mathrm{BU}$ are in the range of 670 to $700{ }^{\circ} \mathrm{C}$ and $1-2 \mathrm{kbar}$. However, fractional crystallization leading to the generation of this magma is likely to have started at an approximate temperature of $750{ }^{\circ} \mathrm{C}$, as indicated by the crystallization temperatures estimated for the CU (Fig. 13; Table 1). These crystallization conditions are in agreement with those predicted in the Qtz-Or-Ab normative diagram (Fig. 4).P-T conditions of the aplopegmatitic dikes surrounding the Belvís pluton are inferred to have been similar to the BU.

\subsection{Chemical constraints on the origin of beryl, chrysoberyl and gahnite. An approach to mineral compatibilities in the BASH system}

The absence of reaction textures between beryl and chrysoberyl contradicts the possibility that the latter was derived by breakdown of primary magmatic beryl, as postulated for some metamorphosed pegmatites (Franz and Morteani, 1984). The presence of idiomorphic to sub-idiomorphic beryl and chrysoberyl crystals included in the main minerals (Fig. 3A-K) suggests an early crystallization of these accessory phases. Furthermore, although the Be-rich cordierite decomposition could be a source for other Be-rich phases, the crystallization of primary beryl co-magmatic with cordierite has also been described (e.g., JobinBevans and Čemý, 1998). Nevertheless, the presence of beryl crystals included in interstitial quartz or feldspars (Fig. 3B-C) implies that this mineral might have also crystallized during late magmatic stages and thus, that the magma was saturated in Be up to the final stages of cooling. Regarding gahnite, there is no textural evidence in the studied rocks to indicate a potential introduction of a Zn-rich hydrothermal fluid (Downes and Bevan, 2002). Tulloch (1981) suggested that the absence of biotite and other major Zn-rich minerals might promote the crystallization of other Zn-bearing magmatic phases and this is in agreement with the presence of gahnite in the Belvís granites. The lack of alteration features, the idiomorphic to sub-idiomorphic shape of gahnite and its presence either disseminated in the rock or included within primary main phases (Fig. 2A-F), suggest an early magmatic origin of this mineral The occurrence of gahnite in the surrounding granite dike swarm also supports a magmatic origin. Hence, all of these textural features, together with their igneous-like chemical composition (Figs. 10A-C, 11A-F), suggest that these $\mathrm{Zn}$-Al-Be-rich minerals crystallized in equilibrium with the other minerals from a felsic peraluminous granite melt.

The most important factors controlling the precipitation of Be-rich minerals are temperature, activity of mineral-forming components ( $\mathrm{BeO}, \mathrm{SiO}_{2}$ and $\mathrm{Al}_{2} \mathrm{O}_{3}$ ) and possible speciation reactions involving fluxing elements (e.g., F, B, Li and P; Charoy, 1999; Evensen et al., 1999). In fact, the diffusivities of Si and Al control the chemical diffusivities of all non-alkali elements (Baker, 1989). Experimental studies have shown that the association of beryl and chrysoberyl may co-exist in moderately to strongly peraluminous magmas (ASI > 1.05; Evensen et al., 1999). A crystal fractionation process involving quartz, two feldspars and biotite may have increased in one order of magnitude the Be content from the central to the border unit of the Belvís pluton (from $5 \mathrm{ppm}$ to $54 \mathrm{ppm}$, respectively; Fig. 6). This is in accordance with experimental data for Be partitioning, calculations on the Be crustal cycle (Evensen and London, 2002; Evensen et al., 1999), and observations in other evolved S-type leucogranites and pegmatites (Charoy and Noronha, 1996; Shearer et al., 1987). This enrichment may result in the precipitation of Be-rich phases, such as beryl and chrysoberyl and the abundance of fluxing components (mainly $\mathrm{P}$ and $\mathrm{B}$ ) may lead to lower crystallization temperatures (London, 1992b; Manning and Pichavant, 1983), thus facilitating beryl saturation (Evensen et al., 1999). Beryl is common in peraluminous granitic rocks both because low BeO contents are required to saturate these ( $\mathrm{Al}-\mathrm{Si}$ )-rich melts in beryl and because they acquire higher BeO contents by mica melting reactions at their source (Evensen et al., 1999). The beryl saturation is reached at tens to few hundreds of ppm BeO in beryl-bearing pegmatites and evolved S-type leucogranites at temperatures between 600 and $650{ }^{\circ} \mathrm{C}$ and at pressures around $200 \mathrm{MPa} \mathrm{H}_{2} \mathrm{O}$, dependent on the temperature and alumina activity at which the crystallization took place (Evensen and London, 2002; Evensen et al., 1999). Hence, the Be contents in the BU leucogranite, although significantly lower than typical values in berylbearing pegmatites (from 100 to $1600 \mathrm{ppm}$; London and Evensen, 2002 , and references therein) and in beryl-bearing granites (145 ppm in the Argemela granite, Portugal; Charoy, 1999), could be enough to reach the beryl saturation at temperatures between 650 and $750{ }^{\circ} \mathrm{C}$. The low averaged temperatures calculated for the Belvis BU (664 and $693{ }^{\circ} \mathrm{C}$; Table 1) favour beryl and chrysoberyl crystallization. The absence of beryllosilicates (e.g., phenakite) and beryllophosphates (e.g., herderite and hurldutite) may be related to low $\mathrm{F}$ and $\mathrm{P}_{2} \mathrm{O}_{5}$ activities in a Si- and Al-rich setting (Barton, 1986; Charoy, 1999; Rao et al., 2011).

There is no correlation between $\mathrm{Zn}$ and Be with differentiation in evolved granites. $\mathrm{Zn}$ is commonly concentrated in residual melts and late stage aqueous solutions during magma differentiation (Holland, 1972), and it is eventually incorporated within late Fe minerals, which leads to an increase in the whole-rock $\mathrm{Zn} / \mathrm{Fe}_{\text {Total }}$ ratio (Batchelor and Kinnaird, 1984; Taylor, 1965). In this regard, it is worth noting that the gahnite-bearing border unit displays higher $\mathrm{Zn} / \mathrm{Fe}_{\text {Total }}$ whole-rock ratios when compared to the other units $\left(\mathrm{Zn} / \mathrm{Fe}_{\text {Total }}>0.01\right.$; Table 1$)$. Nevertheless, Zn-rich phases, such as sphalerite and gahnite, have been found within $\mathrm{H}_{2} \mathrm{O}$ - and $\mathrm{CO}_{2}$-rich melt inclusions in beryl crystals from pegmatites (Thomas et al, 2009; Uher et al., 2010; Zhaolin et al, 1999). These Zn-rich inclusions imply that melts or fluids with high volatile concentrations may promote the transport of rare metals (Thomas et al., 2009), such as $\mathrm{Zn}$ (and Be) as is the case of the Belvís BU and the aplopegmatites.

To explain the accessory mineral assemblage present in the Belvis $\mathrm{BU}$, we have considered the chemical compatibilities between the different co-existing phases in the chemographic $\mathrm{BeO}-\mathrm{Al}_{2} \mathrm{O}_{3}-\mathrm{SiO}_{2}-\left(\mathrm{H}_{2} \mathrm{O}\right)$ system (BASH; Fig. 14A). As illustrated in the BASH system, chrysoberyl is the only aluminous phase compatible with all the minerals described above (Fig. 14A). Beryl and gahnite are not found together in apparent microstructural equilibrium in the studied samples. This is in agreement with the experiments of Evensen et al. (1999), in which in silica- and alumina-saturated conditions the only stable aluminous phase coexisting with beryl is chrysoberyl, and beryl is not stable with other Al-rich minerals such as aluminosilicates (andalusite and sillimanite) or corundum (equivalent to gahnite in Fig. 14A, B). This does not imply that beryl and gahnite cannot be found in the same rock, as shown by the samples from the Belvís BU granite, but they did not crystallize together in the same microtextural domain, clearly suggesting a lack of equilibrium between them.

The mineral assemblage described in the Belvis BU suggests that the melt was silica- and alumina-saturated; hence, the activities of these components ( $\mathrm{Si}$ and $\mathrm{Al}$ ) was extremely high at the beginning of crystallization of the (Be, $\mathrm{Zn}$ )-rich accessory phases. As shown in many experimental studies (see Barton, 1986; Barton and Young, 2002; Evensen et aL, 1999; London and Evensen, 2002), high Si activity in the melt would favour the formation of chrysoberyl and beryl instead of corundum (or gahnite; Fig. 14B). The opposite situation occurs when the melt reaches the highest alumina activity values, which allow the stabilization of the chrysoberyl-gahnite association, but does not permit the co-precipitation of beryl and gahnite (Fig. 14B). We consider that in the Belvis $\mathrm{BU}$, the most plausible context to explain the observed mineral assemblages is the existence of microdomains with variations in the activity of chemical components. Thus, those places in the melt with high alumina activity would precipitate gahnite as the stable Al-rich 


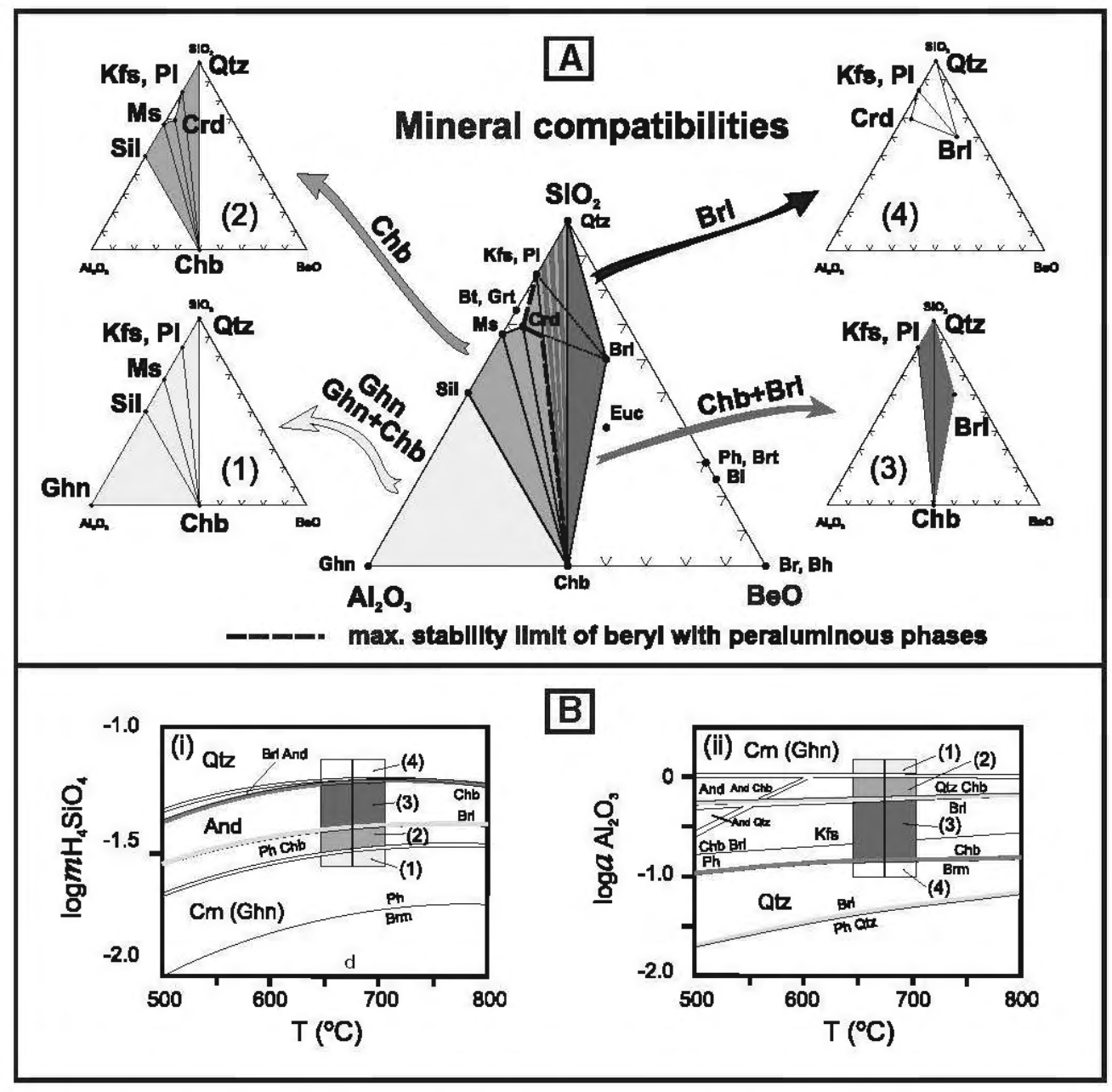

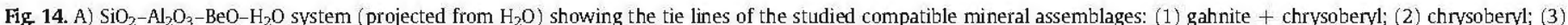

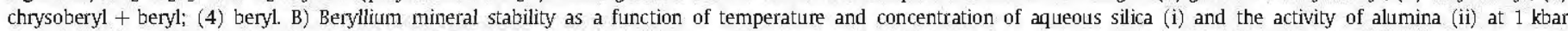

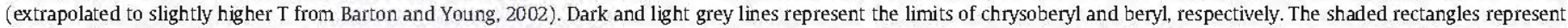

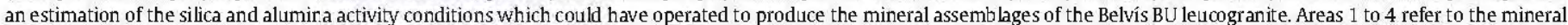
assemblages shown in A. Mineral abbreviations are after Kretz (1983) and as in Fig. 1A.

accessory phase (assemblage 1 in Fig. 14A, B). A further decrease in the activity of this component would promote the stability of $\mathrm{Chb} \pm$ Sill \pm Ms $\pm \mathrm{Kfs} \pm \mathrm{Qtz}$ (assemblage 2 in Fig. 14A, B). As noted above, microdomains with lower alumina activities imply comparatively slightly higher silica activities (Fig. 13B), and this environment would allow the stabilization of $\mathrm{Brl}+\mathrm{Chb} \pm \mathrm{Kfs} \pm \mathrm{Qtz}$ and $\mathrm{Brl} \pm \mathrm{Kfs} \pm \mathrm{Qtz}$ (assemblages 3 and 4 in Fig. 14A, B). As bromellite (Brm) and phenakite $(\mathrm{Ph})$ are not present in the mineral paragenesis, the activities of both silica and alumina must be high (Fig. 14B); therefore, small chemical variations may promote the crystallization of several phases, with the alumina activity being a major controlling factor. Moreover, BeO is usually a minor component which commonly leads to the crystallization of a single saturating Be phase (Barton and Young, 2002). This may explain the preferential crystallization of chrysoberyl instead of beryl in a high Al environment, and the absence of beryl in the aplopegmatitic complex is in agreement with this.

The existence of chemical microdomains within highly felsic leucogranites could be related to models explaining significant chemical changes in a smaller volume of rock than do classical fractional crystallization processes. In this respect, constitutional zone refining (CZR) due to boundary layer liquids (e.g., London and Morgan, 2012) and meltmelt-fluid immiscibility (e.g., Thomas et al., 2012) are among the most recent petrogenetic models for granitic pegmatites and their complex mineralogical (and textural) heterogeneities. Minute blobs and globules of gahnite associated with quartz within large beryl crystals in other granitic pegmatites (Uher et al., 2010; Zhaolin et al., 1999) have been explained as immiscible melt inclusions. The absence of gahnite outside these beryl crystals, casts serious doubt on the coprecipitation of both minerals and equilibrium between them In these studies the co-existence of gahnite and beryl could be explained by the melt-melt immiscibility model (e.g., Thomas et al., 2012; Zhaolin et al., 1999) in which gahnite may be a consequence of crystallization from immiscible droplets of a separate ( $\mathrm{Si}-\mathrm{Al}$ )-rich liquid where $\mathrm{Zn}$ would preferentially migrate. Contrary to this, in the Belvís BU leucogranite, it is more likely that the build-up of fluxing components (e.g., P and B) in a boundary layer associated with crystal growth, and the sequestering of incompatible components within this interface (CZR processes), promoted the formation of microdomains with contrasted chemical features. This process would favour the crystallization of complex Be- and Zn-rich aluminous or silicate mineral assemblages, some of them chemically incompatible (e.g., gahnite-beryl), within mm-size areas.

\section{Conchusions}

The Belvís peraluminous pluton is reversely zoned. The concentration of some elements follows an increasing trend from the central to the border unit, as shown by the enrichment in $\mathrm{P}, \mathrm{Na}, \mathrm{Li}, \mathrm{F}, \mathrm{Rb}, \mathrm{Sr}, \mathrm{Be}$, $\mathrm{B}, \mathrm{Ta}$ and $\mathrm{U}$ both in the whole-rock geochemistry and in the chemistry of the main rock-forming minerals. Trace-element modelling reveals 
that the border unit could be derived by fractional crystallization processes from a parental monzogranitic melt of similar bulk composition to that of the central unit. Nevertheless, the different initial Sr-Nd isotopic signatures of the three leucogranitic units suggest that there was not enough time for homogenization before crystallization. The heterogeneities found both in whole-rock and isotope composition are mostly inherited from the source area. The origin of this reverse zoning is probably related to the ascent of different pulses of mostly co-eval leucogranitic magmas, which previously evolved by fractional crystallization processes within a deeper magma chamber.

An exotic accessory mineral assemblage has been found in the most evolved marginal facies of the pluton composed of gahnite, chrysoberyl and beryl. Such a mineral assemblage within a highly evolved leucogranite has not been described previously in an igneous setting. The absence of replacement textures between beryl chrysoberyl and gahnite, and the main associated minerals, together with other textural and chemical features, suggests a magmatic origin.

$P-T$ conditions for the Belvís pluton can be constrained within the $\mathrm{Al}_{2} \mathrm{O}_{3}$-saturated granite melting curve, and the stability fields for igneous muscovite ( $\mathrm{M}^{\prime}$ curve) and sillimanite, as the accessory mineral paragenesis is stable in a wide range of pressures and temperatures. Hence, estimated conditions are within the range of 670 to $700{ }^{\circ} \mathrm{C}$ and 1-2 kbar.

The crystallization of these minerals seems to be mainly controlled by the melt chemistry, instead of pressure and temperature conditions. The high Al contents and the increase in the concentration of some trace-elements (Be, and $\mathrm{Zn}$ with respect to $\mathrm{Fe}$ ) during granite melt fractionation, could stabilize gahnite, beryl and chrysoberyl as minor accessory minerals. Moreover, the peraluminosity of the melt, together with slight changes of $\mathrm{Si}$ and $\mathrm{Al}$ activities in microdomains, may explain the formation of a complex assemblage of aluminous minerals composed of sillimanite, muscovite, cordierite, gahnite, beryl, chrysoberyl and Alrich phosphates. This mineral association required equilibrium crystallization from a beryllium-, phosphorus-, and boron-rich aluminosilicate melt, in which small changes in the silica and alumina activities promoted the preferential crystallization of beryl + chrysoberyl (higher silica and lower alumina activity) or chrysoberyl + gahnite (lower silica and higher alumina activities) in discrete mm-scaled microdomains.

\section{Acknowledgements}

We thank Alfredo Fernández Larios for his assistance with the electron microprobe analyses in the Centro Nacional de Microscopía Electrónica Luis Bru (UCM). We also thank the valuable comments of an anonymous referee and the highly constructive reviewing done by Dr. Antonio Acosta-Vigil, with which the article has been considerably improved. The corresponding author also wants to acknowledge the excellent treatment received during the period of performing the LA-ICP-MS analyses at The Natural History Museum of London. This research received support from the SYNTHESYS project http:// www.synthesys.info/ which is financed by European Community Research Infrastructure Action under the FP7 Integrating Activities Programme. This work is included in the objectives of, and supported by, the CGL2012-32822 project of the Ministerio de Economía y Competitividad of Spain, and the 910492-UCM group.

\section{References}

Ábalos, B., Carreras, J., Druguet, E., Escuder, J., Gómez-Pugnaire, M.T., Lorenzo Álvarez, S., Quesada, C., Rodriguez-Fernández, R., Gil-Ibarguchi, J.I., 2002. Variscan and preVariscan tectonics. In: Gibbons, W., Moreno, T. (Eds.), The Geology of Spain. Geological Society of London, pp. 155-183.

Alfonso, P., Melgarejo, J.C., 2008. Fluid evolution in the zoned rare-element pegmatite field at Cap the Creus, Catalonia, Spain. Canadian Mineralogist 46, 597-617.
Allen, C.M., 1992. A nested diapir model for the reversely zoned Turtle Pluton, southeastern California. Transactions of the Royal Society of Edinburgh: Earth Sciences 83, 179-190. Andonaegui, P., 1990. Geoquímica y geocronología de los granitoides del Sur de Toledo. (Ph.D. Thesis) Complutense University, Madrid 1-357 (in Spanish).

Andonaegui, P., Villaseca, C., 1998. Granites from the Mora-Gálvez Pluton (Toledo): an example of evolution by crystal fractionation. Boletín de la Real Sociedad Española de Historia Natural 94, 17-31 (in Spanish).

Antunes, I., 2008. Geochemistry of S-type granitic rocks from the reversely zoned Castelo Branco pluton (central Portugal). Lithos 103, 445-465.

Armbruster, T., Imuschek, A, 1983. Cordierites from the Lepontine Alps: $\mathrm{Na}+\mathrm{Be} \rightarrow \mathrm{Al}$ substitution, gas content, cell parameters, and optics. Contributions to Mineralogy and Petrology 82, 389-396.

Baker, D.R, 1989. Tracer versus trace element diffusion: diffusional decoupling of $\mathrm{Sr}$ concentration from Sr isotope composition. Geochimica et Cosmochimica Acta 53 (11), 3015-3023.

Barton, M.D., 1986. Phase equilibria and thermodynamic properties of minerals in the $\mathrm{BeO}-\mathrm{Al}_{2} \mathrm{O}_{3}-\mathrm{SiO}_{2}-\mathrm{H}_{2} \mathrm{O}$ (BASH) system, with petrologic applications. American Mineralogist 71, 277-300

Barton, M.D., Young, S., 2002. Non-pegmatitic deposits of beryllium: mineralogy, geology, phase equilibria and origin. In: Grew, E.S. (Ed.), Beryllium: Mineralogy, Petrology, and Geochemistry. Reviews in Mineralogy, 50. Mineralogical Society of America, pp. 591-691.

Batchelor, RA, Kinnaird, JA., 1984. Gahnite compositions compared. Mineralogical Magazine 48, 425-429.

Bea, F., Pereira, M.D., Corretgé, LG., Fershtater, G.B., 1992. Differentiation of strongly peraluminous granites: the Pedrobernardo pluton, central Spain. Geochimica et Cosmochimica Acta 58, 2609-2627.

Castiñeiras, P., Villaseca, C., Barbero, L., Martín Romera, C., 2008. SHRIMP U-Pb zircon dating of anatexis in high-grade migmatite complexes of Central Spain: implications in the Hercynian evolution of Central Iberia. International Journal of Earth Sciences 97 , $35-50$.

Cerný, P., 1991. Rare element granitic pegmatites. Part I: anatomy and internal evolution of pegmatite deposits. Geoscience Canada 18, 29-47.

Cerný, P., Anderson, A.J., Tomascak, P.B., Chapman, R., 2003. Geochemical and morphological features of beryl from the Bikita granitic pegmatite, Zimbabwe. The Canadian Mineralogist 41, 1003-1011.

Charoy, B., 1999. Beryllium speciation in evolved granitic magmas: phosphates versus silicates. European Journal of Mineralogy 11, 135-148.

Charoy, B., Nomnha, F., 1996. Multistage growth of a rare-element volatile-rich microgranite at Argemela (Portugal). Journal of Petrology 37, 73-94.

Chattopadhyay, P.K., 1999. $\mathrm{Zn}$-spinel in the metamorphosed $\mathrm{Zn}-\mathrm{Pb}-\mathrm{Cu}$ sulphide deposit at Mamand ur, southern India. Mineralogical Magazine 63 (5), 743-755.

Clemens, J.D., Stevens, G., 2012. What controls chemical variation in granitic magmas? Lithos 134-135, 317-329.

D'Amico, C., Rottura, A., Bargossi, G.M., Nannetti, M.C., 1981. Magmatic genesis of andalusite in peraluminous granites. Examples from Eisgarn type granites in Moldanubicum. Rendiconti della Società Italiana di Mineralogia e Petrologia 38, $15-25$.

Debon, F., Le Fort, P., 1983. A chemical-mineralogical classification of common plutonic rocks associations. Transactions of the Royal Society of Edinburgh: Earth Sciences 73, 135-149.

Downes, P.J., Bevan, W.R, 2002. Chrysoberyl, beryl and zincian spinel mineralization in granulite-facies Archaean rocks al Dowerin, Western Australia. Mineralogical Magazine $66,985-1002$

Evensen, J.M., London, D., 2002. Experimental silicate mineral/melt partition coefficients for beryllium and the crustal Be cycle from migmatite to pegmatite. Geochimica et Cosmochimica Acta 66, 2239-2265.

Evensen, J.M., London, D., 2003. Experimental partitioning of Be, Cs, and other trace elements between cordierite and felsic melt, and the chemical signature of S-type granite. Contributions to Mineralogy and Petrology 144, 739-757.

Evensen, J.M., London, D., Wendlandt, R.F., 1999. Solubility and stability of beryl in granitic melts. American Mineralogist 84, 733-745.

Franz, G., Morteani, G., 1984. The formation of chrysoberyl in metamorphosed pegmatites. Journal of Petrology 25, 27-52.

Ghosh, B., Some, S., Thakur, A, 2011. Petrogenesis of zincian spinel from Mamandur base metal sulphide prospect, Tamil Nadu. Journal of the Geological Society of India 78 , 365-369.

González del Tánago, J., 1991. Las pegmatitas graníticas de Sierra Albarrana (Córdoba, España): Mineralizaciones de berilio. Boletín Geológico y Minero de España 102, 90-114. Groat, LA., Giuliani, G., Marshall, D.D., Turner, D., 2008. Emerald deposits and occurrences: a review. Ore Geology Reviews 34, 87-112.

Hecht, L, Vigneresse, J.L., 1999. A multidisciplinary approach combining geochemical, gravity and structural data: implications for pluton emplacement and zonation. Geological Society of London, Special Publication 168, 95-110.

Heimann, D.J., Spry, P.G., Teale, G.S., 2005. Zincian spinel associated with metamorphosed Proterozoic base-metal sulphide occurrences, Colorado: a re-evaluation of gahnite composition as guide in exploration. The Canadian Mineralogist 43, 601-622.

Holdaway, M.J., Mukhopadhyay, B., 1993. Stability of andal usite and the aluminosilicate diagram. American Journal of Science 271, 97-131.

Holland, H.D., 1972. Granites, solutions and base metals deposits. Economic Geology 67 (3), 281-301.

Icenhower, J., London, D., 1995. An experimental study of element partitioning among biotite, muscovite, and coexisting peraluminous silicic melt at $200 \mathrm{MPa}\left(\mathrm{H}_{2} \mathrm{O}\right)$. American Mineralogist 80, 1229-1251.

Icenhower, J., London, D., 1996. Experimental partitioning of Rb, Cs, Sr, and Ba between alkali feldspar and peraluminous melt. American Mineralogist 81, 719-734. 
IGME, 1985. Mapa geológico de España, Hoja no. 653, Valdeverdeja Servicio de Publicaciones Ministerio de Industria, Madrid.

IGME, 1987. Mapa geológico de España, Hoja no. 652, Jaraicejo. Servicio de Publicaciones Ministerio de Industria Madrid.

IGME, 1989. Mapa geológico de España, Hoja no. 654, El Puente del Arzobispo. Servicio de Publicaciones ITGE, Madrid.

Jacobson, R., Webb, J.S., 1947. The occurrence of nigerite, a new tin mineral in quartzsillimanite rocks from Nigeria. Mineralogical Magazine 28, 118-128.

Janoušek, V., Rogers, G., Bowes, D.R., Van̆ková, V., 1997. Cryptic trace-element variation as an indicator of reverse zoning in a granitic pluton: the Ričany granite, Czech Republic. Journal of the Geological Society $154,807-815$.

Jobin-Bevans, S., Cerný, P., 1998. The beryllian cordierite + beryl + spessartine assemblage, and secondary beryl in altered cordierite, Green Lake granitic pegmatites, southeastern Manitoba. The Canadian Mineralogist 36, 447-462.

Johannes, W., Holtz, F., 1996. Petrogenesis and Experimental Petrology of Granitic Rocks. Springer-Verlag, Berlin 1-335.

Kerrick, D.M., Speer, JA., 1988. The role of minor element solid solution on the andalusitesillimanite equilibrium in metapelites and peraluminous granitoids. American Journal of Science 288, 152-192.

Kontak, D.J., Martin, RF., Richard, L, 1996. Patterns of phosphorus enrichment in alkali feldspar, South Mountain Batholith, Nova Scotia, Canada. European Journal of Mineralogy $8,805-824$.

Kretz, R., 1983. Symbols for rock-forming minerals. American Mineralogist 68, 277-279.

Liñán, E., Gozalo, R., Palacios, T., Gámez-Vintaned, JA., Ugidos, J.M., Mayoral, E., 2002 Cambrian. In: Gibbons, W., Moreno, T. (Eds.), The Geology of Spain. Geological Society of London, pp. 17-29.

London, D., 1992a. Phosphonus in S-type magmas: the $\mathrm{P}_{2} \mathrm{O}_{5}$ content of feldspars from peraluminous granites, pegmatites, and rhyolites. American Mineralogist 77, 126-145.

London, D., $1992 \mathrm{~b}$. The application of experimental petrology to the genesis and crystallization of granitic pegmatites. Canadian Mineralogist 30, 499-540.

London, D., Evensen, J.M., 2002. Beryllium in silicic magmas and the origin of berylbearing pegmatites. In: Grew, E.S. (Ed.), Beryllium: Mineralogy, Petrology, and Geochemistry. Reviews in Mineralogy, 50. Mineralogical Society of America, pp. 445-486.

London, D., Morgan VI, G.B., 2012. The pegmatite puzzle. Elements 8, 263-268.

Lukkari, S., Holtz, F., 2007. Phase relations of a F-enriched peral uminous granite: an experimental study of the Kymi topaz granite stock, southern Finland. Contributions to Mineralogy and Petrology 153, 273-288.

Luth, W.C., Jahns, R.H., Tuttle, O.F., 1964. The granite system at pressures of 4 to 10 kilobars. Joumal of Geophysical Research 69, 759-773.

Manning, DA.C., 1981. The effect of fluor ine on liquidus phase relationships in the system Qz-Ab-Or with excess water at $1 \mathrm{~kb}$. Contributions to Mineralogy and Petrology 76, 206-215.

Manning, DA.L, Pichavant, M., 1983. The role of fluorine and boron in the generation of granitic melts. In: Atherton, M.P., Gribble, C.D. (Eds.), Migmatites, Melting and Metamorphism. Shiva, Nantwich, pp. 94-109.

Montel, J.M., 1993. A model for monazite/melt equilibrium and application to the generation of granitic magmas. Chemical Geology 119, 127-146.

Montel, J.M., Weber, C., Pichavant, M., 1986. Biotite-sillimanite-spinel assemblages in high-grade metamorphic rocks: occurrences, chemographic analysis and thermobarimetric interest. Bulletin de Mineralogie 109, 555-573.

Nabelek, P.I., Papike, J.J., Laul, J.C, 1986. The Notch Peak granitic stock, Utah: origin of reverse zoning and petrogenesis. Journal of Petrology 27, 1035-1069.

Orejana, D., Merino, E., Villaseca, C., Pérez-Soba C., Cuesta, A., 2012. Electron microprobe monazite geochronology of granitic intrusions from the Montes de Toledo batholith (central Spain). Geological Joumal 47, 41-58.

Pattison, D.R.M., 1992. Stability of andalusite and sillimanite and the $\mathrm{Al}_{2} \mathrm{SiO}_{5}$ triple point: constraints from the Ballachulish aureole, Scotland. American Mineralogist 86, 1414-1422.

Pereira, M.D., Bea, F., 1994. Cordierite-producing reactions in the Peña Negra complex, Ávila batholith, Central Spain: the key role of cordierite in low-pressure anatexis. The Canadian Mineralogist 32, 763-780.

Pérez-Soba, C., Merino, E., Villaseca, C., Orejana, D., 2009. Zr-REE-Y-rich accessory minerals from peraluminous granites of the Montes de Toledo batholith (Iberian Hercymian Belt). Macla 11, 145-146.

Pérez-Soba, C., Villaseca, C., Orejana, D., Jeffreys, T., 2013. U-rich accessory minerals in the peraluminous and perphosphorous granites of the Belvis de Monmy pluton (Iberian Variscan Belt). Contributions to Mineralogy and Petrology (submitted for publication).

Pichavant, M., 1987. An experimental study of the effect of boron on a water saturated haplogranite at 1 kbar vapour pressure. Geological applications. Contributions to Mineralogy and Petrology 76, 430-439.
Pichavant, M., Kontak, D.J., Valencia Herrera, J., Clark, A.H., 1988. The Miocene-Pliocene Macusani Volcanics, SE Peru. I. Mineralogy and magmatic evolution of a two-mica aluminosilicate-bearing ignimbrite suite. Contributions to Mineralogy and Petrology $100,300-324$.

Rao, C., Wang, R.C., Hu, H., 2011. Paragenetic assemblages of beryllium silicates and phos phates from the Nanping No. 31 granitic pegmatite dyke, Fujian Province, southeastem China. The Canadian Mineralogist 49, 1175-1187.

Reyes, J., Villaseca, C., Barbero, L., Quejido, A.J., Santos Zald uegui, J.F., 1997. Description of a $\mathrm{Rb}, \mathrm{Sr}, \mathrm{Sm}$ and $\mathrm{Nd}$ separation method for silicate rocks in isotopic studies. I Congreso Ibérico de Geoquímica, Abstract Vol, pp. 46-55 (in Spanish).

Shearer, C.K., Papike, J.J., Laul, J.C., 1987. Mineralogical and chemical evolution of a rareelement granite-pegmatite system; Harney Peak Granite, Black Hills, South Dakota. Geochimica et Cosmochimica Acta 51, 473-486.

Shearer, C.K., Papike, J.J., Jolliff, B.L, 1992. Petrogenetic lonks among granites and pegmatites in the Harney Peak rare-element granite-pegmatite system, Black Hills, South Dakota. Canadian Mineralogist 30, 785-809.

Soares, D.R., Beurlen, H., Ferreira, A.C.M., da-Silva, R.R., 2007. Chemical composition of gahnite and degree of pegmatitic fractionation in the Borborema Pegmatitic Province, northeastern Brazil. Anais da Academia Brasileira de Ciências 79 , $395-404$.

Soman, K., Nair, N.G.K., 1985. Genesis of chrysoberyl in the pegmatites of Southern Kerala, India. Mineralogical Magazine 49, 733-738.

Spry, P., 1987. Compositional zoning in zincian spinel. The Canadian Mineralogist 25 97-104.

Spry, P., Scott, S., 1986. The stability of zincian spinels in sulfide systems and their potential as exploration guides for metamorphosed massive sulphide deposits. Economic Geology 81, 1446-1463.

Sun, S.S., McDonough, W.F., 1989. Chemical and isotopic systematics of oceanic basalts: implications for mantle composition and pmcesses. In: Saunders, A.D., Norry, M.J. (Eds.), Magmatism in the Ocean Basins. Geological Society of London Special Publications, 42, pp. 313-345.

Taylor, S.R, 1965. Application of trace elements data to problems in petrology. Physics and Chemistry of the Earth 6, 133-213.

Thomas, R, Davidson, P., Badanina, E., 2009. A melt and fluid inclusion assemblage in beryl from pegmatite in the Orlovka amazonite granite, East Transbaikalia Russia: implications for pegmatite-forming melt systems. Mineralogy and Petrology 96, 129-140.

Thomas, R, Webster, J.D., Davidson, P., 2011. Be-daughter minerals in fluid and melt inclusions: implications for the enrichment of $\mathrm{Be}$ in granite-pegmatite systems. Contributions to Mineralogy and Petrology 161 (3), 483-495.

Thomas, R., Davidson, P., Beurlen, H., 2012. The competing models for the origin and internal evolution of granitic pegmatites in the light of melt and fluid inclusion research. Mineralogy and Petrology 106, 55-73.

Tindle, A.G., Breaks, F.W., 1998. Oxide minerals of the Separation Rapids rare-element granitic pegmatite group, northwestem Ontario. The Canadian Mineralogist 36 $609-635$.

Tulloch, A.J., 1981. Gahnite and columbite in an alkali-feldspar granite from New Zealand. Mineralogical Magazine 44, 275-278.

Tuttle, O.F., Bowen, N.L, 1958. Origin of Granite in the Light of Experimental Studies in the System $\mathrm{NaAlSi}_{3} \mathrm{O}_{8}-\mathrm{KAlSi}_{3} \mathrm{O}_{8}-\mathrm{SiO}_{2}-\mathrm{H}_{2} \mathrm{O}$. Geological Society of America (Mem 74).

Uher, P. Chudík, P. Bacík, P., Vaculovic, T., Galiová, M., 2010. Beryl composition and evolution trends: an example from granitic pegmatites of the beryl-columbite subtype, Western Carpathians, Slovakia. Journal of Geosciences 55, 69-80.

Valladares, M.I., Barba, P., Ugidos, J.M., 2002. Precambrian. In: Gibbons, W., Moreno, T. (Eds.), The Geology of Spain. Geological Society of London, pp. 7-16.

Villaseca, C., Barbero, L, 1994. Chemical variability of $\mathrm{Al}-\mathrm{Ti}-\mathrm{Fe}-\mathrm{Mg}$ minerals in peraluminuos granitoid rocks from Central Spain. Eumpean Journal of Mineralogy 6, 691-710.

Villaseca, C. Barbero, L, Herreros, V., 1998. A re-examination of the typology of peraluminous granite types in intracontinental orogenic belts. Transactions of the Royal Sociely of Edinburgh: Earth Sciences 89, 113-119.

Villaseca, C., Pérez-Soba, C., Merino, E., Orejana, D., López-García, JA., Billström, K., 2008. Contrasting crustal sources for peraluminous granites of the segmented Montes de Toledo Batholith (Iberian Variscan Belt). Joumal of Geosciences 53, 263-280.

Watson, E.B., Harrison, T.M., 1983. Zircon saturation revisited: temperature and composition effects in a variety of crustal magma types. Earth and Planetary Science Letters 64, 295-304.

Wise, M., Brown, C., 2010. Mineral chemistry, petrology and geochemistry of the Sebago granite-pegmatite system, southern Maine, USA. Journal of Geosciences 55, 3-26.

Zhaolin, L., Zhang, W., Yang, R, Li, W., Zhai, W., 1999. Analysis of chemical composition of melt inclusion of beryl in pegmatite and discovery of zinc-spinel by electronic probe. Chinese Science Bulletin 44, 2004-2010. 